\title{
A vállalatikötvény-piac gazdasági szerepének növekvő jelentősége*
}

\author{
Bécsi Attila - Bognár Gergely - Lóga Máté
}

A vállalati kötvények szerepe globálisan felértékelődött az elmúlt évtizedben, mivel ideális pénzügyi eszközök mind a kibocsátó vállalatok forrásszerkezetének diverzifikálásában, mind pedig a befektetők portfóliójának kezelésében. Egy kellően fejlett és likvid vállalatikötvény-piac jótékony hatással van a gazdaság piaci mechanizmusainak érvényesülésére, átláthatóságára, valamint erösítheti a pénzügyi rendszer válságállóságát is. Több tanulmány is rámutatott arra, hogy a vállalatok finanszirozásának kérdése a cégek normális müködésén túl a válságkezelésben is kiemelten fontos, mivel egy krízist övező bizonytalanság negativ hatással van a bankhitelezés likviditására, megnehezítve a vállalati forrásbevonási lehetőségeket. Ilyen helyzetben létfontosságú tehát, hogy a társaságok egyéb finanszírozási formákra is támaszkodni tudjanak. A 2008-2009-es gazdasági válságot követően ezt felismerve számos ország jegybankja is kötvényvásárlási programot indított annak érdekében, hogy támogatni kezdje a vállalati kötvények piacának szélesítését. A Magyar Nemzeti Bank (MNB) Növekedési Kötvényprogramjának (NKP) köszönhetöen már a hazai vállalatikötvény-piac is a vállalatok széles köre számára kínál a bankhitelek melletti reális finanszírozási alternatívát.

Journal of Economic Literature (JEL) kódok: G01, E52, E58, G15

Kulcsszavak: vállalatikötvény-piac, eszközvásárlási program, gazdasági és pénzügyi válság, monetáris politika

\section{Bevezetés}

A 2008-2009-es gazdasági és pénzügyi világválság a pénzügyi rendszer számos olyan strukturális problémájára fényt derített, amelynek kiküszöbölése elengedhetetlen a piacok ellenállóbbá tételéhez egy újabb krízishelyzet esetén. Ezek közé tartozik a vállalati forrásbevonás diverzifikálásának jelentősége, ugyanis az olyan bankhitelek

\footnotetext{
* A jelen kiadványban megjelenő írások a szerzők nézeteit tartalmazzák, ami nem feltétlenül egyezik a Magyar Nemzeti Bank hivatalos álláspontjával.

Bécsi Attila a Magyar Nemzeti Bank elemzője. E-mail cím: becsia@mnb.hu Bognár Gergely a Magyar Nemzeti Bank elemzője. E-mail cím: bognarg@mnb.hu Lóga Máté a Magyar Nemzeti Bank igazgatója. E-mail cím: logam@mnb.hu

Jelen tanulmány a szerzők nézeteit tartalmazza, amely nem feltétlenül egyezik meg a Magyar Nemzeti Bank hivatalos álláspontjával. A tanulmány megállapításait, következtetéseit a szerzők 2021. szeptember 30-i záró dátum figyelembe vételével tették.
}

A magyar nyelvű kézirat első változata 2020. június 17-én érkezett szerkesztőségünkbe.

DOI: http://doi.org/10.25201/HSZ.20.4.537 
melletti alternatív finanszírozási módok, mint a kötvénykibocsátás, további lehetőségeket teremtenek a társaságoknak a forráshoz jutásra a bankhitelezési likviditás csökkenése esetén is. A vállalati kötvények hosszú távú, kiszámítható finanszírozási lehetőséget biztosítanak a vállalatoknak, emellett pedig számos további előnnyel is rendelkeznek: a kötvények révén bevont forrást nem feltétlenül kötik fedezethez és konkrét hitelcélhoz, a kötvénypiaci jelenlét pedig az értékpapírokat forgalomba hozó vállalat transzparens múködését demonstrálja, ami a későbbiekben akár egy részvénykibocsátás előszobáját is jelentheti. A fent említett előnyök tükrében a tanulmány a vállalatikötvény-piac értékének növekedését feltételezi a 2008-2009-es válságot követően, az így létrejött, diverzifikáltabb piac pedig megmutathatja, hogy mennyivel lehet hatékonyabb a Covid19 okozta válság kezelése a korábbi krízishez képest. Számos gazdaságban a fejlett és likvid kötvénypiac hozzájárulhat a Covid19járvány okozta gazdasági visszaesés hatásainak csökkentéséhez, különösen, ha ott a jegybank is megjelenik vásárlóként.

A vállalatikötvény-piac finanszírozásban betöltött súlyát számos tényező befolyásolja, ilyen például a gazdasági fejlettség, a tőkepiac hatékonysága, a vállalatok pénzügyi kultúrája vagy akár befektetők védelmét is szolgáló szabályozói és intézményi környezet. A kötvénykibocsátás egy adott értékpapírsorozat karakterisztikájának alakítása révén rendkívül rugalmas finanszírozási eszköz lehet, melynek segítségével egyedi vállalati szinten optimális forrásbevonási struktúra érhető el, a vállalati kötvények elterjedése ugyanakkor makrogazdasági szinten is kedvező hatással bír. A jelentősebb gazdaságok jegybankjai által folytatott vállalatikötvény-vásárlási programok szintén azt tanúsítják, hogy az eszköznek komoly jelentőséget tulajdonítanak a monetáris politikai döntéshozók. A tanulmány következő, 2. fejezete a vállalati kötvények általános szerepét, a 3. fejezet a kötvénypiac globális és regionális helyzetét mutatja be, külön kiemelve a regionális piacokat. A 4. rész a jegybankok vállalatikötvény-vásárlási programjait vizsgálja, az 5. fejezet pedig részletesen ismerteti a magyar vállalatikötvény-piacot és a Növekedési Kötvényprogramot. A 6. fejezet a tanulmány legfontosabb megállapításait összegzi. 


\section{A vállalati kötvények általános szerepe}

\subsection{A vállalati kötvény tulajdonságai}

A kötvény egy olyan hitelviszonyt megtestesítő értékpapírtípus, amelyen keresztül különböző gazdasági szereplők (állam, vállalat, bank) valamilyen felhasználási cél mellett forrásbevonást hajthatnak végre. A kötvényszerződésben foglaltak szerint az értékpapírt megvásárló tulajdonosok jogosultak a kölcsönadott tőkére, az ahhoz kapcsolódó nominális kamatfizetésre (kupon), illetve amennyiben a kötvény átruházható, úgy eladási joggal is rendelkeznek. A kötvények lejáratáig fennálló időszakot futamidőnek hívjuk, ami jellemzően hosszabb, mint amit bankhitelek esetében tapasztalhatunk. A kamatfizetést a szerződés alapján előre meghatározott napokon fizeti az adós, miközben a tőke visszafizetése megkezdődhet a futamidő lejárta előtti időpontokban (amortizálódó kötvények), vagy történhet a futamidő végén egy összegben (bullet típusú kötvények). A vállalatikötvény-piacon a kötvények széles spektruma megtalálható, ám amíg a kevésbé fejlett piacokon általában a legegyszerübb struktúrájú (plain vanilla) kötvények túlsúlya jellemző, addig a fejlettebb tőkepiacokon gyakoriak az összetettebb, különböző opcionalitást tartalmazó termékek is. ${ }^{1} \mathrm{~A}$ kamatozás típusa szerint megkülönböztetünk fix kamatozású kuponnal kibocsátott kötvényeket és változó kamatozású értékpapírokat, ${ }^{2}$ utóbbiak esetében egy referencia-kamatlábhoz kötött ráta, illetve az arra épülő spread fizetése történik a kamatfizetés időpontjaiban.

A kötvények tulajdonságainak, paramétereinek alakítása rendkívül rugalmassá, ennélfogva vonzóvá teheti a kötvénykibocsátást a vállalatok számára, amelyek így a forrásbevonást a számukra egyénileg leginkább hatékony módon valósíthatják meg.

\footnotetext{
${ }^{1}$ Az opciókat (call, put) tartalmazó kötvények lehetőséget teremtenek az értékpapírok előre meghatározott áron való visszaadására vagy visszavásárlására. Ugyancsak megemlítendők az átváltható, opciós kötvények (convertible bonds), amelyek a kötvény futamideje alatt bizonyos időpontokban, előre meghatározott áron részvényre válthatók át, általában a kötvénybirtokos döntése szerint.

2 Ezenfelül léteznek speciális kamatozású kötvények is, mint például a „step-up” (elöre meghatározott fix kamatozás, azonban a futamidő alatt annak mértéke változik) értékpapírok, vagy a „cap” (maximum) és "floor" (minimum) használata is megjelenhet az esedékes kamatfizetés során. A kötvénypiacokon különös terméknek számítanak a természetben fizető kötvények („,pay-in-kind”), amivel - elsősorban alacsonyabb hitelminősítésű, nehéz pénzügyi helyzetben lévő vállalatok - az esedékes kuponfizetéseket nem készpénzzel, hanem a vállalat döntésének értelmében újabb kötvénykibocsátással valósítják meg.
} 


\begin{tabular}{|c|c|}
\hline \multicolumn{2}{|c|}{$\begin{array}{l}\text { 1. táblázat } \\
\text { A kötvényfinanszírozáshoz köthető legfőbb előnyök }\end{array}$} \\
\hline Szempont & A kötvénnyel járó előny \\
\hline Befektetői bázis & $\begin{array}{l}\text { A kötvénypiacon széleskörű, belföldi és külföldi befektetői bázis is megjelenik, így } \\
\text { a bankhitelhez képest jelentősebb mértékű forrásbevonás valósítható meg anélkül, } \\
\text { hogy az a banki nagyadósi limitbe ütközne. }\end{array}$ \\
\hline Fedezet & $\begin{array}{l}\text { A kibocsátó végrehajthat fedezetlen vagy fedezett forrásbevonást, utóbbi esetében } \\
\text { jellemzően tovább szélesíthető a befektetői kör. }\end{array}$ \\
\hline Futamidő & $\begin{array}{l}\text { A (fedezetlen) bankhitelekhez képest jellemzően hosszabb a futamidő, ami a hosz- } \\
\text { szabb távú és fenntartható finanszírozást támogatja. }{ }^{3}\end{array}$ \\
\hline Hitelcél & $\begin{array}{l}\text { Kötvények esetében általában nincsen szűken vett hitelcél, a forrást szabadon hasz- } \\
\text { nálhatja fel a kibocsátó. }\end{array}$ \\
\hline A vállalat mérete & $\begin{array}{l}\text { Jellemzően az érett szakaszban lévő nagyvállalatok élnek a kötvénykibocsátással, } \\
\text { ugyanakkor számos növekedési fázisban járó vállalatot segíthet potenciáljának kiak- } \\
\text { názásában. }\end{array}$ \\
\hline Árazás & $\begin{array}{l}\text { A vállalatikötvény-piac árazása vonzó alternatívát kínálhat a bankhitelekhez képest. } \\
\text { Amennyiben a cégek forrásellátottságát biztosító piacok között verseny alakul ki, } \\
\text { a finanszírozási költségek tovább mérséklődhetnek a vállalati szektor számára. }\end{array}$ \\
\hline Bankkapcsolat & $\begin{array}{l}\text { A kötvénypiac lehetőséget ad a bankkapcsolatok optimalizálására és a bankoktól való } \\
\text { függés enyhítésére. }\end{array}$ \\
\hline Válságkezelés & $\begin{array}{l}\text { A bankhitelezés befagyása esetén is likviditáshoz juthat a kötvénykibocsátó. A forrás- } \\
\text { bevonás felgyorsulhat, különösen, ha a vállalatikötvény-piacon egy jegybank megjele- } \\
\text { nik vásárlóként. }\end{array}$ \\
\hline PR-szempontok & $\begin{array}{l}\text { A kötvénykibocsátás a tőzsdén kedvezőbb megítélést hozhat a kibocsátónak, mivel } \\
\text { transzparensebb működést demonstrál, ezért gyakorlatilag a részvénypiacra történő } \\
\text { belépés előszobájának is tekinthető. }\end{array}$ \\
\hline Jogosultságok & $\begin{array}{l}\text { Call opció esetén a vállalatnak joga van visszavásárolni a kötvényeit, ami a kamatlábak } \\
\text { csökkenésekor lehet ideális. }\end{array}$ \\
\hline $\begin{array}{l}\text { Tulajdoni és } \\
\text { szavazati jogok } \\
\text { megtartása }\end{array}$ & $\begin{array}{l}\text { Részvénykibocsátással szemben a kötvényen keresztüli forrásbevonás esetében } \\
\text { a befektetők tulajdoni és szavazati joghoz nem jutnak, a vállalat nyereségéből és az } \\
\text { osztalékból csak a mindenkori tulajdonosi kör részesedik. }\end{array}$ \\
\hline
\end{tabular}

Az 1. táblázat alapján látható, hogy a vállalatok számára számos érv szól a kötvénykibocsátás mellett, ezek kiaknázására azonban csak akkor van lehetőség, ha a kibocsátandó kötvényeik esetében a kínálat találkozik a befektetői kereslettel. A befektetők portfóliójukat gyakran diverzifikálják vállalati kötvényekkel, mivel így számos esetben a befektetői profiljukhoz közelebb álló kockázat/hozam eszközöszszetétel érhető el. A kötvény ideális pénzügyi eszköz lehet azok számára, akik közvetlenül szeretnének vállalatokat finanszírozni, mivel ezt jellemzően alacsonyabb kockázatokkal tehetik meg, mintha ezt a részvénypiacon keresztül tennék meg. $\mathrm{E}$ feltételezés mellett érvel Distenfeld - Shah (2014), amely szerint ha egy portfólióban

\footnotetext{
${ }^{3}$ A magyarországi vállalati hitelek forintban denominált része eredeti futamidejének kevesebb mint fele volt 5 évnél hosszabb a 2020-as évben, az euróban denominált hitelek esetében is csupán 50-60 százalék közötti arányt értek el az 5 évnél hosszabb futamidejü hitelek. Ezzel szemben az MNB Növekedési Kötvényprogramjának keretében kibocsátott vállalati kötvények mindegyikének eredeti futamideje legalább 7 éves volt, az össznévértékkel súlyozott átlagos futamidő pedig 9,3 év.
} 
amerikai egyesült államokbeli magas hozamú kötvényeket tartanánk 25 százalékos arányban, maradék háromnegyedét pedig az S\&P 500 által leképezett részvényekből állítanánk össze, úgy az éves kockázat 15,2 százalékról 12,8 százalékra mérséklődne, míg a hozam csak minimálisan, 10,9 százalékról 10,7 százalékra csökkenne az 1983 júliusa és 2013 decembere közötti adatokat vizsgálva.

A kötvények esetében a befektetők kamatnyeresége és tőkefizetése pontosabban kiszámítható, ami a pénzügyi stabilitási szempontokat figyelembe véve kedvező. A befektetők kockázata elsősorban a piaci hozam változásából fakadó árfolyammozgás, hiszen amennyiben a pénzpiacon az elvárt hozam emelkedik, a kötvényen vesztesége keletkezik a befektetőknek. Ugyancsak kockázati tényező lehet, ha egy kötvény fedezetlen, annak tulajdonosait ugyanis a jogszabály hátrébb lévő kielégítési kategóriába sorolja be, mintha az értékpapír mellé biztosítékok is társulnának. A hitelkockázat arra utal, hogy a kibocsátó milyen valószínűség szerint mulasztja el az adósság teljes mértékben és pontos időben történő visszafizetését. A kibocsátók hitelképességéről és kötvényeik hitelkockázatáról a fejlettebb piacokon hitelminősítők fogalmaznak meg véleményt, különböző kategóriába sorolva az instrumentumokat. Alapvető eltérés a befektetésre javasolt és a spekulatív, ún. high-yield-kötvények között áll fenn. Számos nagy intézményi befektető csupán az előbbiekkel kereskedhet, valamint a 2020 előtti jegybanki kötvényvásárlási programok zöme is elsősorban a befektetésre ajánlott kötvények piacára fókuszált, így a két kategóriába tartozó papírok piaci likviditása és a rajtuk keresztüli forrásbevonás költsége között számottevő különbség lehet.

A kötvények természetéből fakadóan egyéb kockázattípusokról is beszélhetünk, úgymint a devizakockázat, az opcióból fakadó kockázat és a likviditási kockázat, melyekről a befektető többek között a kötvények dokumentációjából is értesülhet. Ezek közül a szakirodalomban leggyakrabban a likviditási kockázat kerül górcső alá. Több felmérés is a másodpiacokon megfigyelhető likviditás romló tendenciájára hívta fel a figyelmet. A CFA Intézet (2016) felmérésében részt vevő amerikai és európai befektetési szakértők a banki tőke- és likviditási szabályozásokat jelölték meg a probléma fő forrásaként, s orvoslásuk érdekében döntéshozói lépéseket sürgettek a piaci akadályok feloldására. Az ázsiai válaszadók szerint ugyanakkor a kisbefektetői részvétel ösztönzése fontosabb lehet, mint az intézményi befektetői piac javítása. Hill et al. (2019) a csökkenő likviditást elsősorban az érvényben lévő jogszabályoknak és rendkívüli monetáris politikai lépéseknek tulajdonítják, ugyanakkor kihangsúlyozzák a piacteremtő likviditási modell aláásásának jelenségét is, ami elsősorban a brókerek és a kereskedők megnövekedett tőkekötelezettségeivel magyarázható. A gyenge likviditás problémája nem újkeletű. Gyntelberg és szerzőtársai (2005) már a válság előtt is foglalkoztak az ázsiai másodpiacok illikviditásával, melynek okaként a szúk befektetői kört, a nem megfelelő mikrostruktúrákat és a kibocsátókkal kapcsolatos információs hiányt jelölték meg. 


\subsection{A vállalatikötvény-piac fontossága egy diverzifikált pénzügyi rendszer kiala- kulásában}

A vállalatikötvény-piac fontos elemét képezi egy kellőképpen diverzifikált és hatékony pénzpiacnak, a banki hitelezést kiegészítő alternatív forrásbevonási módok iránti igény ugyanis az elmúlt évtizedben szignifikánsan emelkedett. Luengnaruemitchai - Ong (2005) már a 2008-as globális válság előtt megállapította, hogy a vállalatok forrásbevonásának diverzifikációja kedvező folyamat, különösen bankválságok esetén, és elsősorban egyes feltörekvő országokban. Szintén a vállalatikötvény-piac kedvező hatásait vizsgálta Hakansson (1999) is, aki megállapította, hogy egy fejlett kötvénypiac erősen pozitív hatással bír a gazdaságra, mivel amennyiben a bankhitel finanszírozásban betöltött szerepe túlságosan nagy, a laza hitelezési kritériumok miatt a befektetett tőke megtérülése mérséklődhet, ami végső soron a nemteljesítő hitelek emelkedéséhez vezethet. Amennyiben a bankrendszer és a kötvénypiac egyensúlyban van, a piaci folyamatok jobban érvényesülni tudnak, ami csökkenti a szisztematikus kockázatokat és egy potenciális válság kialakulásának kockázatát. Tendulkar és Hancock (2014) az elmúlt 30 évben történt vállalatikötvény-kibocsátásokat megvizsgálva arra jutottak, hogy az utóbbi évtizedekben egyre fontosabbá vált a kötvénypiac szerepe a reálgazdaságban, és a válság óta a kötvények a banki hitelezés és a hosszú távú finanszírozás közötti űr kitöltésében is meghatározók. A tanulmány szerint az alacsony hozamkörnyezetben a hozamvadászat támogatja a kötvénypiac likviditását, a hozamkörnyezet változása azonban veszteseket és nyerteseket egyaránt szülhet. Az ICMA (2013) vállalati kötvényekkel foglalkozó tanulmánya megállapítja, hogy a gazdasági szereplők széles körének (befektetők, vállalatok, kormány) fontos egy fejlett, likvid kötvénypiac megléte, mivel az a gazdasági növekedésre is kedvezően hathat, hiszen a reálgazdaság szempontjából kiemelten fontos termelővállalatok stabil és megbízható finanszírozási csatornát találhatnak a kötvénypiac képében, miközben a befektetők kiszámítható bevételhez juthatnak. Míg a kisebb vállalatok döntően a belföldi vállalatikötvény-piacokon lehetnek aktívabbak, addig a nagyvállalatok az intézményi befektetőket szélesebb körben felvonultató nemzetközi kötvénypiac adta lehetőségeket is ki tudják használni.

Lund et al. (2018) ugyancsak pozitív jelenségként tekint a vállalatikötvény-piac növekedésére, különös tekintettel annak a transzparencia növekedésében, a piac hatékonyságának javításában, valamint a kockázatkezelésben betöltött szerepére. Gostkowska-Drzewicka (2014) a lengyelországi ingatlanfejlesztő társaságok vállalatikötvény-piacát elemezve szintén kiemeli a kötvénykibocsátás előnyeit: a kibocsátó több kötvénybirtokoson keresztül tud jelentős méretű forrást bevonni, különösen jól használható finanszírozási forma a fejlesztési projektek esetén, mivel a kibocsátó határozza meg a visszafizetés ütemét és a lejáratot, így a kibocsátó a már teljesült beruházásokból származó bevételekből válthatja vissza a kötvényt. További kedvező jellemzője a kötvényeknek, hogy a tőkeköltség alacsonyabb lehet, mint bankhitel 
igénybevétele esetén, különös tekintettel, ha a kötvényhez valamilyen egyéb kitételt, így például részvényre történő átváltási opciót kapcsolnak.

\subsection{A kötvénypiac jelentősége a pénzügyi válságban}

Egy kellően likvid és fejlett vállalatikötvény-piacra érdemi szerep hárulhat egy esetleges pénzügyi válság esetén, mivel tompíthatja a krízis erejét, a kilábalás időtartamát pedig lerövidítheti. De Fiore és Uhlig (2015) megállapította, hogy a krízis miatt visszaeső banki likviditás a nem pénzügyi vállalatokat a korábban meghatározó bankhitel-finanszírozástól a kötvénykibocsátás felé mozdította el, habár mindkét finanszírozási forma költségei növekedtek. A szerzők egy DSGE-modell használata révén arra a következtetésre jutottak, hogy egy válság idején a gazdaság abban az esetben szenvedi el a legnagyobb visszaesést, ha a banki finanszírozás nem képes megfelelően rugalmas szolgáltatást nyújtani a cégek számára, és eközben a tőkepiac sem áll rendelkezésre. A tanulmány amellett érvel, hogy amennyiben a vállalatok finanszírozási lehetőségei rugalmasak, és a cégek képesek az egyes forrásbevonási módok között választani, úgy a reálgazdaságban egy válság potenciális, a pénzügyi szektorból begyűrűző negatív hatásai mérsékelhetők.

Gyntelberg et al. (2005) révén az ázsiai pénzügyi válságon keresztül vizsgálható meg egy másik régió kötvénypiacának alakulása, mely az országonként szignifikáns eltérést mutató ázsiai piac helyzetét elemzi. A szerzők szerint megfigyelhető, hogy az 1997-es ázsiai pénzügyi válság óta a kötvénypiac jelentős prioritást élvez a döntéshozók körében, akik a helyi pénznemben kibocsátott kötvénypiacokban gyakran egy következő válság elkerülésének lehetőségét látják, melyen keresztül csökkenhetnek az egyes pénznemekből és lejáratokból adódó kockázatok. A kötvénypiacok nyitottságát tekintve eltérések figyelhetők meg: míg egyes elsődleges piacok nyitva állnak a külföldi kibocsátók előtt, addig mások (például Kína, India vagy Új-Zéland) a kvázi-kormányzati kibocsátókra támaszkodnak. Gormley et al. (2006) szerint az 1998-as dél-koreai válságban a kötvénypiacról bevont források adták a vállalati finanszírozás szinte teljes egészét, ami hozzájárult ahhoz, hogy a háztartások is megjelenhessenek a vállalatok közvetlen finanszírozásában. A szerzők a vállalatikötvény-piac válság alatti szerepét leginkább egy pótkerékhez hasonlítják, habár hangsúlyozzák, hogy a kötvénypiac nyújtotta forrásbevonási lehetőség elsősorban a nagyvállalatok számára volt nyitott, aminek következtében egy, a hitelpiacnál jóval koncentráltabb piac alakult ki. A válságból adódó tanulságokat levonva a 2000-es évek eleje óta az ázsiai döntéshozók számos országban felfigyeltek a vállalati kötvényekre, felismerték, hogy egy erős pénzügyi rendszernek többféle finanszírozási csatornára van szüksége, amelyben a bankok és más típusú befektetők versengenek a hitelfelvevőkért. Ahogyan azt az ázsiai pénzügyi válság is bemutatta, a hitelezői pánik a rövid távú hitelpiacokat sújtja, a vállalatikötvény-piac viszont jelentős, hosszú távú finanszírozást biztosíthat a gazdaság számára, így a vállalati kötvények elsődleges piaca szükségszerűen és számottevően növekedett. 
A kötvénypiac válságok után megfigyelt dinamikus bővülése egyúttal felvetette a fenntarthatóság kérdését is. Lund et al. (2018) a globális adósságállomány 2008 óta tartó folyamatos növekedését vizsgálta. A vállalatikötvény-kibocsátások 2,5-szeresükre növekedtek az elmúlt évtizedben, aminek révén számos országban egy széleskörübb és mélyebb piac jött létre. Ahogyan arra más tanulmányok is rámutattak, a pénzügyi válság óta számos nagyvállalat mozdult el világszerte a kötvényfinanszírozás felé, mert a kereskedelmi bankok visszafogták a hitelezést. A kutatás megjelenésekor a globális vállalati adósság mintegy 20 százaléka testesült meg kötvények formájában, ami közel duplája a 2007-es aránynak. A tanulmány írói szerint a vállalatikötvény-piac mélyülése, valamint a vállalati finanszírozás diverzifikációja pozitívan hat a globális pénzügyi piacokra, azonban kockázatokat is rejt, ugyanis a befektetésre nem javasolt kategóriájú kötvények állománya csaknem megduplázódott 2007 és 2017 között, a fejlett országok társaságainak esetében elérve az 1,7 billió dollár értéket. A tanulmány kiemelte továbbá azt is, hogy 2018 és 2022 között rekord nagyságú kötvényállomány jár le, így a megújítási kockázat korábban nem látott méreteket ölthet. A tanulmány azt is feszegeti, hogy a globális vállalatikötvény-piac mérete tovább fog-e emelkedni a hitelciklus fordulatát és a kamatlábak emelkedését követően. Noha számos kockázat árnyalja az összképet, mégis jelentős mozgástér áll rendelkezésre a további növekedéshez, ugyanakkor ennek megvalósulásához mind a hitelintézeteknek, mind a szabályozási keret megalkotóinak alkalmazkodniuk kell a változó körülményekhez. Azok a bankok, amelyek eddig a nagyvállalatok hitelezésére koncentráltak, most inkább a KKV-kra és az egyénekre összpontosíthatnak, emellett javítaniuk kell a jegyzési és hitelbírálati képességeiket, és növelniük a költséghatékonyságukat. A tanulmány mintegy ajánlásként megfogalmazza, hogy a politikai döntéshozók és szabályozók ösztönözzék az elektronikus kereskedési platformok felé történő elmozdulást, várják el a transzparenciát a vállalati beszámolókban, és kísérjék figyelemmel az esetleges rendszerszintű kockázatokat.

\section{A vállalatikötvény-piac globális és regionális helyzete}

\subsection{A nemzetközi kötvénypiac helyzete}

Az elméleti háttér bemutatását követően érdemes megvizsgálni, hogy a globális szinten jelentős gazdaságok mennyiben támasztják alá a tanulmányokban megfogalmazott állításokat, azaz milyen folyamatok olvashatók ki a nemzetközi vállalatikötvény-piac alakulásából az elmúlt évtizedekben. 2020 végére a nem pénzügyi vállalatok által globálisan kibocsátott kötvényállomány a BIS adatai szerint elérte a történelmi csúcsot jelentő 17 billió dollárt. A dinamikus növekedés a 2008-as globális pénzügyi válság óta tart, 2019 és 2020 során az állomány összesen közel 3,4 billió dollárral nőtt. A folyamatot érdemben támogatták a vezető jegybankok monetáris politikai eszköztárában mind a piacépítő, mind a Covid19-válság nyomán válságkezelő elemként szereplő kötvényvásárlási programok. A jelentős 
adósságállomány ugyanakkor veszélyeket is hordoz, hiszen - ahogy arra Çelik et al. (2020) is felhívja a figyelmet - a jelenlegi adósságstruktúra változásában négy negatív trend azonosítható: gyengébb az átlagos kötvényminőség, magasabb a refinanszírozási kockázat, hosszabb a futamidő, illetve gyengébb a befektetői védelem. A megváltozott adósságállomány-összetétel, különösen a koronavírusjárvány-helyzet miatti gazdasági visszaesés globálisan problémát okozhat a vállalati szektorban. Egyrészt kérdést vet fel, hogy amennyiben a jelenlegi alacsony hozamkörnyezet megváltozik, a csődkockázatok mennyire fognak emelkedni, másrészt a feltörekvő piacok globális vállalatikötvény-állományon belüli arányának növekedése az átlagos kötvényminőség további romlását vonhatja maga után. Az átlagos hitelminősítés és a csődráták között természetesen pozitív, szoros összefüggés van. Vazza et al. (2019) kiemeli, hogy míg a AAA, AA és A minősítésű kötvények esetében 2009 és 2018 között nem fordult elő nemfizetés, és a BBB minősítésű instrumentumok tekintetében is csupán 0,06 százalékos csődráta figyelhető meg, addig a 2018-as évet vizsgálva a B minősítésűek 0,98 százaléka, a CCC/C kategóriának pedig 27,2 százaléka volt nemteljesítő. ${ }^{4}$ Tovább erősíti az összefüggést az a tény, hogy 2018-ban az összes, S\&P által minősített nemfizető kötvény a spekulatív, nem befektetésre ajánlott kategóriába tartozott, 87,5 százalékuk B-, vagy annál alacsonyabb minősítéssel rendelkezett az év elején.

Ennek tükrében különösen feltűnő, hogy míg a 2000-es évek elején 30-35 százalék körül alakult a BBB minősítésű kötvények aránya (a BBB+és a BBB- sávon belül), addig 2019-re már a kötvények fele a kategória alsó határát jelentő BBB- minősítéssel rendelkezett. $E$ trenddel összhangban a legjobb minősítésű AAA kötvények aránya 1 százalék alá csökkent, miközben a AA minősítésű papírok aránya is 8 százalék alá esett. A nem befektetésre ajánlott kötvénykategórián belül a legjobb minősítésűnek számító BB kötvények aránya a 2000-es évek óta dinamikusan emelkedik, 2019 végére 60 százalékra nőve a 2000 elején mért 30 százalékról (1. ábra). Ennek hátterében az állhat, hogy több BB alatti kibocsátó elhagyta a kötvénypiacot, és a tőkeáttételes hitelpiacra tért át a 2008-as pénzügyi válságot követően. A kötvénypiacon egy esetlegesen bekövetkező leminősítési hullám jelentős problémákat okozhat, mivel amennyiben egyes kötvények átkerülnek a befektetésre nem ajánlott kategóriába, számos intézményi befektető a konzervatívabb befektetési politikája miatt eladási kényszerbe kerülhet. Ez a magatartás ugyanakkor a Covid19-járvány alatt mérséklődött, mivel több jegybank is úgy alakította ki kötvényvásárlási programjának célcsoportját, hogy figyelembe vegye a pandémia okozta leminősítések hatását is. A gyengébb minősítésű kötvények növekedésével összhangban a befektetők fokozottabb védelme is előtérbe került, ami különösen fontos tényező az alacsony hozamkörnyezetben. A befektetésre ajánlott kategórián belül a kovenánsok által védett kötvények aránya az USA kötvénypiacán 15-20 százalék körül alakult

\footnotetext{
${ }^{4}$ 2018-ban a BB minősítésű kötvények közül nem került ki nemfizető papír.
} 
az elmúlt években. Ezzel szemben a nem befektetésre ajánlott kötvényeknél 2000 és 2012 közötti időszakban fokozatos csökkenés tapasztalható a kovenánssal ellátott kötvények arányánál (47 százalékról 30 százalékra), azonban a válság utáni években már emelkedett a ráta. 2019 végén a befektetésre ajánlott kategóriában tapasztalt értékhez képest érdemben magasabban, 38 százalékon állt a mutató. Ezen kovenánsok jelentős része a vállalat eszközeinek értékesítésére, valamint a további eladósodottsággal állnak összefüggésben (Çelik et al. 2020). A vállalati kötvények kockázatának növekedése miatt felértékelődött a vállalatok transzparens múködésének jelentősége, és a vállalatok kockázatát objektíven, függetlenül leíró hitelminősítések szerepe.

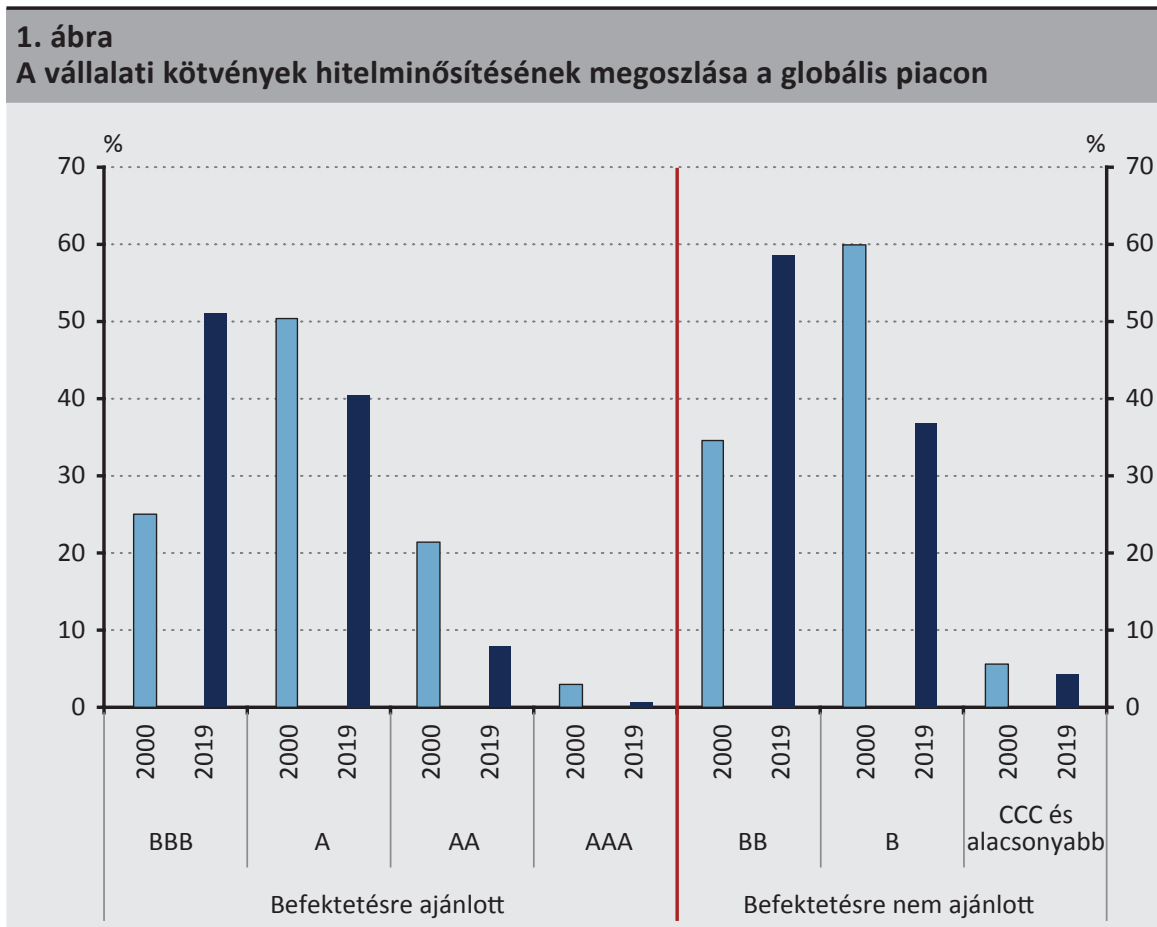

Forrás: OECD Capital Market Series dataset, Thomson Reuters Eikon

Egy adott ország vállalatikötvény-piaca méretének meghatározására az egyik leggyakoribb mutatószám a kötvények összesített állományának GDP-hez viszonyított aránya, mivel ennek segítségével hatékonyan nyomon követhető, hogy a piaci állomány aránya milyen mértékben változik a gazdaság egészéhez képest. Azt a feltevést, hogy a vállalati kötvények aggregátuma világszerte egyre nagyobb a bruttó hazai termék arányában, a BIS és az Eurostat ${ }^{5}$ vonatkozó adatai is megerősítik (2. ábra).

${ }^{5}$ Forrás: A Bank of International Settlements (BIS) adatbázisa (https://stats.bis.org/statx/srs/table/c1) és az Eurostat adatbázisa (https://appsso.eurostat.ec.europa.eu/nui/show.do?dataset=nasq_10_f_bs\&lang=en) 


\section{2. ábra}

A vállalatikötvény-állomány GDP-arányos alakulása a világ vezető gazdaságaiban

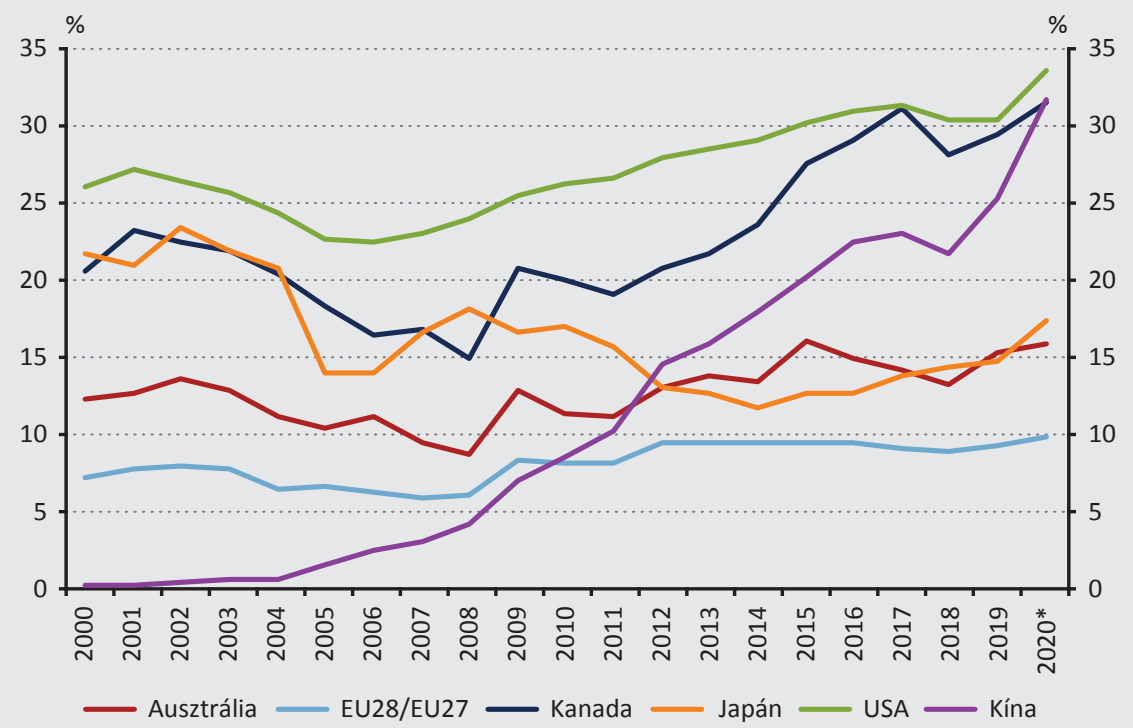

Megjegyzés: * A kötvénypiacok 2020 év végi adatok esetében a kötvényállomány-adatokat a 2019. évi GDP-adatokkal osztottuk le, mivel a 2020. éviek még nem álltak rendelkezésre. Az EU27/28 országoknál a tagállamok GDP-arányos kötvényállományainak átlaga került feltüntetésre.

Forrás: BIS, OECD, Eurostat

Japán kivételével az 5 legnagyobb vállalatikötvény-piaccal rendelkező országban és az EU-ban a válság előtti 7-8 évben a GDP-arányos vállalatikötvény-állomány csökkenő trendet mutatott, a tendenciát a 2008-as globális válság törte meg, ami után, bár eltérő dinamikában, de összességében mindegyik jelentősebb kötvénypiacon nőtt a nem pénzügyi vállalatok kötvényeinek állománya. A globális vállalatikötvény-állomány növekedésében jelenleg Kína játssza az egyik legfontosabb szerepet. Az ázsiai nagyhatalom GDP-arányos vállalatikötvény-állománya a 2000-es években még elhanyagolható, 1 százalék alatti értékről a 2008-as válságot követően kezdett dinamikus növekedésbe, 2020 végére pedig már meghaladta a 4,5 billió dollárt, vagyis a GDP 32 százalékát. A dinamikus növekedés hátterében döntően az állami vállalatok kötvénykibocsátásai állnak. Az ázsiai vállalatikötvény-piacon Kína mellett dél-koreai, malajziai és szingapúri vállalatok is aktívnak mutatkoznak. A feltörekvő ázsiai országokhoz képest lassabb dinamikával, de a vállalatikötvény-állomány szintén bővült a feltörekvő latin-amerikai országokban, ami alapvetően a brazil, mexikói és chilei vállalatok értékpapírjainak forgalomba hozatalához kötődik. 
Az angolszász országokban a tőkepiaci finanszírozás hagyományosan elterjedt a vállalatok forrásbevonásában. A vállalati kötvények nagysága a GDP-hez mérten az Egyesült Államokban a legnagyobb, 2020 végére meghaladva a 34 százalékot, ami megközelítőleg 8 százalékponttal magasabb a 2000-es értéknél. Nagyjából hasonló arány figyelhető meg Kanada esetében is, ahol azonban a 2008-2009-es gazdasági válság idején visszaesett a kötvényállomány, a 2000-ben mért 21 százalékos értékről 15 százalékra. Ezt követően azonban jelentős növekedés figyelhető meg: a vállalatikötvény-adósság aránya a GDP-hez mérten 2015 óta 30 százalék körüli szinten mozog, 2020-ban historikus csúcsot jelentő 32 százalékot tett ki. A többi angolszász országhoz képest jóval alacsonyabb az ausztrál vállalatikötvény-volumen GDP-hez viszonyított aránya, valamint az elmúlt 20 évben nem is volt megfigyelhető jelentős növekedés. A 2000-ben 12 százalékos érték 2020 végére 16 százalékra emelkedett, azonban az idősorban - a kanadai példához hasonlóan - kisebb törést okozott 2008ban a pénzügyi válság.

Az előbb bemutatott fejlett országok példájával szemben Japán kivételnek tekinthető, ugyanis a vállalati kötvények aránya a GDP-hez mérten csökkenő trendet mutat: a 2000-ben megfigyelt 22 százalékos értékről a vizsgált időszak végére 18 százalékra csökkent a mutató. Ennek oka, hogy a japán vállalati forrásbevonásban alapvetően a banki hitelezés dominanciája figyelhető meg, habár a pandémiás vészhelyzet kezdete óta a japán vállalati szektor ismét némileg nagyobb mértékben támaszkodik a kötvénypiacról történő finanszírozásra.

Az Európai Unió 28 országának tekintetében a GDP-arányos vállalatikötvény-állomány a szóban forgó 20 éves periódusban kis mértékben, 7 százalékról 10 százalékra emelkedett 2020 végére. Ez az arány a japán és az ausztrál értékekhez hasonló, de jelentősen elmarad az USA, Kanada, valamint Kína piacainak méretétől.

\subsection{Az európai uniós kötvénypiac helyzete}

Az Európai Unión belül az egyes tagállamok kötvénypiacainak fejlettsége jelentős különbséget mutat: míg egyes országokban a kötvényállományok mérete a GDP 30 százaléka körül mozog, addig a kelet-közép-európai tagállamokban és a balti térségben jellemzően 5 százalék alatti a mutató (3. ábra). Az európai uniós országokat megvizsgálva kirajzolódik, hogy a gazdasági fejlettség és a vállalatikötvény-piac mérete között pozitív kapcsolat figyelhető meg. A fejlett, magasabb egy főre eső GDP-vel rendelkező országokban a vállalati eladósodottság is jellemzően magasabb, vagyis a tőkepiac aktívabb használata figyelhető meg. A pozitív kapcsolat ellenére találhatunk olyan országokat az EU-ban, ahol a fejlettséghez viszonyítva a kötvénypiac aránya alacsonyabb, vagy magasabb: Németországban és Dániában a kötvénypiac 7-8 százalékos GDP-arányos mérete relatíve alacsonynak számít, miközben a Portugáliában mérhető 16 százalékos szint messze meghaladja a hasonló fejlettségű országokban tapasztalható értéket. 


\section{3. ábra}

Az EU-tagállamok nem pénzügyi vállalati kötvényállományának GDP-arányos mérete (2020)

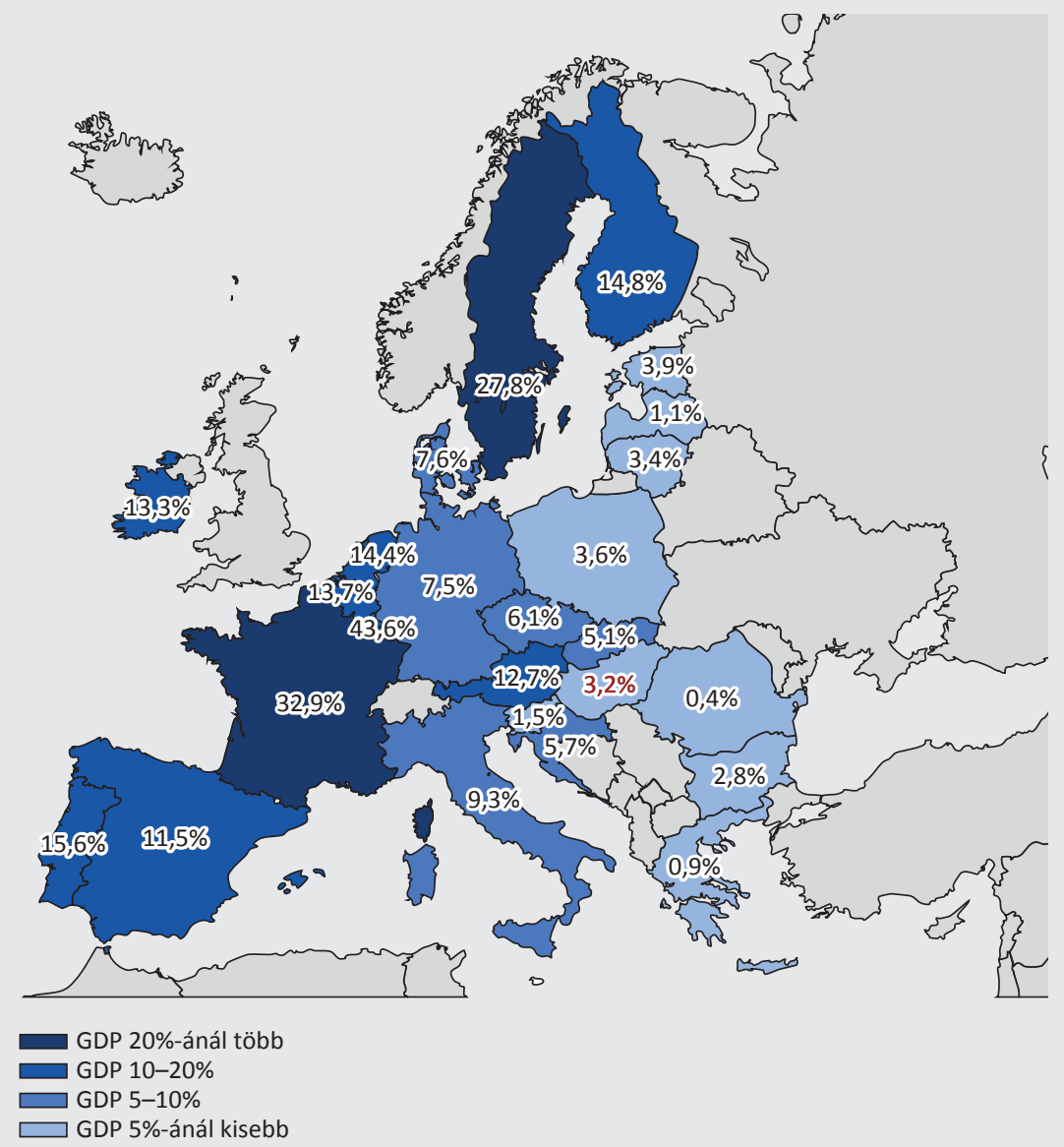

Forrás: Eurostat

A kötvénypiac fejlettsége két országban kiemelkedő mértékú: 2020 végén Franciaországban és Svédországban a nem pénzügyi vállalatok kötvényállománya a bruttó hazai termék 33 , illetve 28 százalékát is megközelítette. ${ }^{6} \mathrm{~A}$ francia kötvénypiacon jellemzően a részben állami tulajdonú vállalatok és a multinacionális nagyvállalatok aktívak, míg Svédországban a regionális kormányzati és önkormányzati tulajdonban lévő kibocsátók aránya nagyobb, mint a többi piacon. A teljes Európai

\footnotetext{
${ }^{6}$ Az EU legfejlettebb kötvénypiacával Luxemburg rendelkezik, ahol a vállalati kötvények állománya 2020 végén a GDP 44,6 százalékával volt egyenértékű, ugyanakkor nominálisan számítva a helyi piac mérete nem tartozott az uniós tagállamok élmezónyébe.
} 
Unióban 10 százalék, míg az euroövezeti országok tekintetében átlagosan 14,9 százalék a vállalati kötvények aránya a GDP-hez mérten. Az EU átlaga feletti fejlettséggel rendelkező kötvénypiacok jellemzően a nyugati és a skandináv országok piacai közül kerülnek ki.

A vállalatikötvény-piac felértékelődésének vizsgálatához érdemes szemügyre venni a vállalatok forrásszerkezetének időbeli alakulását. A kötelezettségek szerkezete ugyanis megmutatja, hogy a társaságok számára milyen hitelezési lehetőségek adottak: a vállalatok finanszírozásában mekkora a hitelezők és a tulajdonosok egymáshoz viszonyított aránya, illetve mekkora a tőkepiaci forrásbevonás jelentősége. Ha kimondottan az eurozóna országaiban vizsgáljuk a bankhitel és kötvénypiac alakulását, az elmúlt két évtizedben az rajzolódik ki, hogy míg a hitelállomány dinamikusan bővült 2008-ig, addig a kötvénypiac jellemzően stagnált. A válság éveiben a hiteltranzakció jelentősen visszaesett, és a válságot követő 5-6 évben döntően negativ tartományban volt, vagyis a hitelállomány mérséklődött. Ezzel szemben az eurozóna kötvénypiaca dinamikus bővülése következtében a korábbi 600-700 milliárd euróról 2020 végére 1700 milliárd euro közelébe emelkedett. Szembetűnő az is, hogy míg a válság óta a kötvénypiac finanszírozói szerepe folyamatos és stabil növekedést mutat, addig a tőzsdei részvények és hitelek aránya a vállalati finanszírozáson belül sokkal hektikusabb. A vállalati kötvények állományának változása mellett elemzésre érdemes a kötvények vállalatfinanszírozáson belüli részarányának változása is. Az Eurostat adatai szerint míg 2000 végén az eurozónában a kötvények forrásoldali súlya nem érte el a 4,7 százalékot, addig 2010-ben már 6,8 százalékot tett ki, 2020-ban pedig már megközelítette a 8,7 százalékot, vagyis a kötvények jelentette hosszabb távú, stabilabb finanszírozás jelentősége egyre figyelemreméltóbb. A hitelek - mindenekelőtt a bankhitelek - természetesen továbbra is a vállalati adósságállomány legjelentősebb szeletét képezik, azonban a bankhiteleknek fontos alternatívát nyújtó tőkepiacok kiegészítő szerepe egyre intenzívebbnek mondható (4. ábra). 


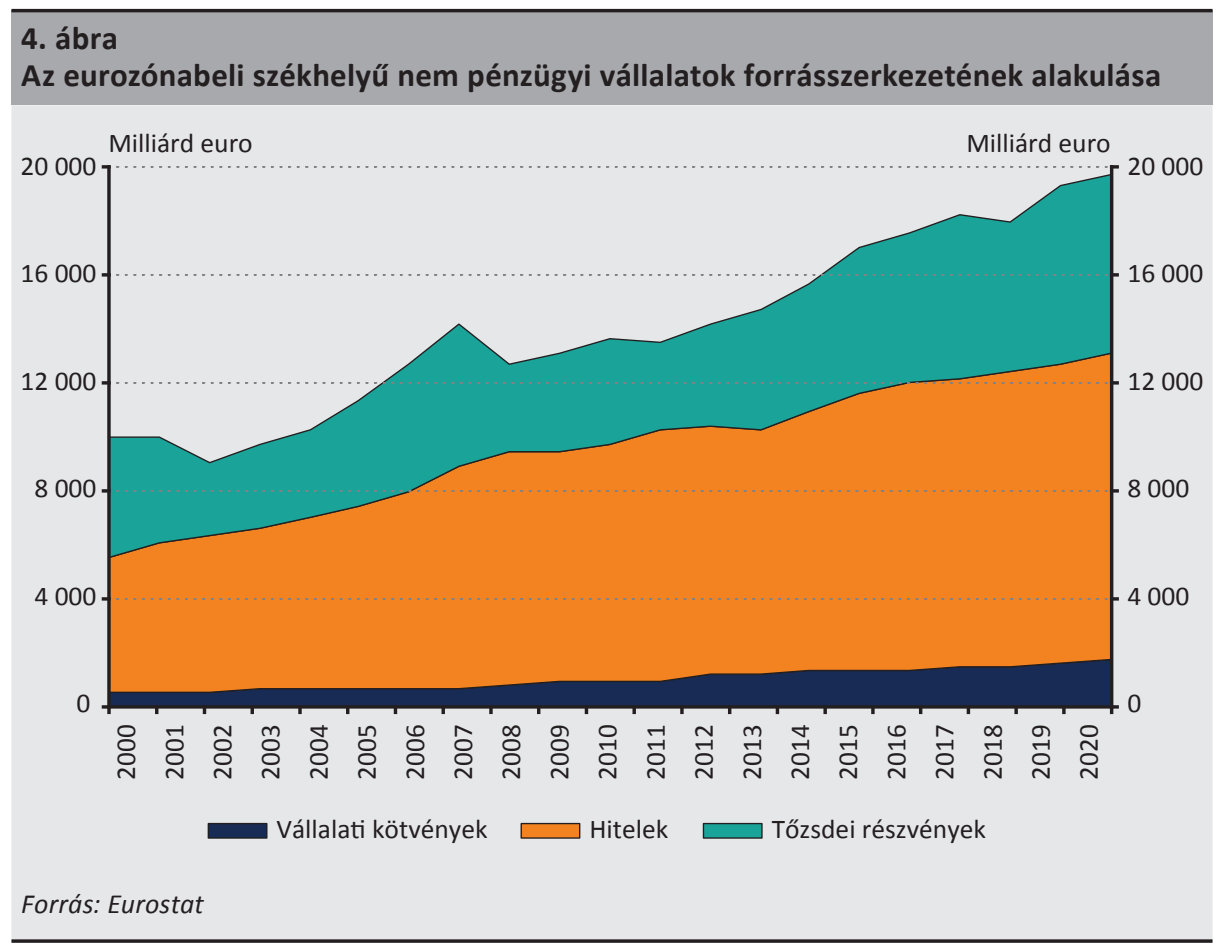

Az európai uniós kötvénypiac fejlődését az elmúlt 20 év adatai alapján elemezve érdekes következtetésre juthatunk. Az országok piacai öt nagy csoportba oszthatók földrajzi elhelyezkedésük és kötvénypiaci fejlettségük együttes vizsgálata révén. Az idősoros adatokon egyértelműen látszik, hogy a mediterrán országokat leszámítva szinte minden országcsoportban felértékelődött a kötvénypiac szerepe az elmúlt évtizedben, és 2020 során - elsősorban a koronavírus-járvány negatív hatásait mérséklő jegybanki kötvényvásárlási programoknak köszönhetően - valamennyi uniós régió piaca növekedni tudott (5. ábra). 


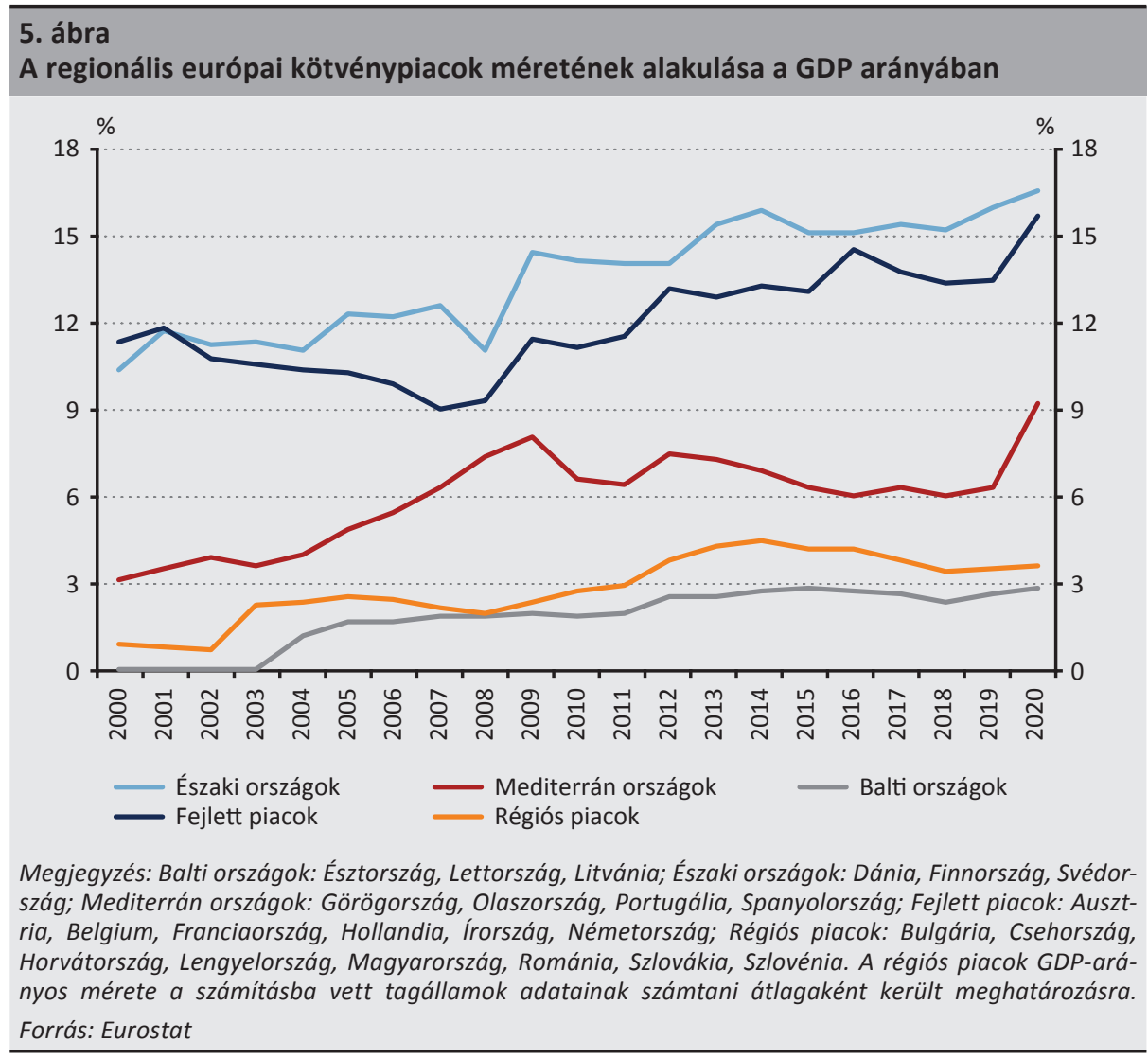

Jelenleg a legfejlettebb régió a skandináv országok piaca, ahol a kötvénypiaci állományok átlaga a GDP 17 százalékát is megközelíti, és a fejlődés mértékét tekintve is a térség piacai léptek előre a legnagyobbat: a GDP-hez viszonyított régiós arány 2000-ról 2020 végére 6,3 százalékponttal növekedett. A fejlett piacokon a 2000-es évek elején a kötvénypiac visszaesése volt tapasztalható, amely a 2008-as gazdasági válságig tartott, azóta a GDP-arányos állománybővülés kisebb megszakításokkal ugyan, de folyamatos. A mediterrán piacok a többi régióval ellentétes fejlődési pályát jártak be: míg a vállalati kötvények állománya a globális krízisig intenzív növekedést mutatott, addig a válság után - döntően a görög kötvénypiac összeomlásának, valamint a portugál piac 2013-tól kezdődő összezsugorodásának köszönhetően mérséklődött a kötvényvolumen. A balti országok és a régiós piacok országai esetén a kötvénypiac beindulása figyelhető meg a vizsgált időszakban. Míg a 2000-es évek elején 1 százalék alatt volt a vállalatikötvény-piacok mérete, addig 2020 végére átlagosan 3,6 százalékra növekedtek. A kontinensre 2020 elején begyürüző koronavírus-járványból fakadó gazdasági nehézségekre Európa számos jegybankja reagált célzott vállalatikötvény-vásárlási program elindításával, ami jelentősen hozzájárult ahhoz, hogy 2020-ban valamennyi vizsgált országcsoport GDP-arányosan számított 
átlagos piaca növekedni tudjon, sőt a mutató a közép-európai térség piacait leszámítva az összes régióban az elmúlt 20 év legmagasabb értékén álljon.

\subsection{A közép-kelet-európai régió kötvénypiacának helyzete}

A régiós országok kötvénypiacának részletesebb vizsgálatához az elemzés körébe a V4 országok mellett a román és a szlovén piac is bevonásra került. A GDP-arányos vállalati kötvényvolumen alapján a cseh, szlovák és lengyel kötvénypiac a legfejlettebb, de az elmúlt két év növekedésének köszönhetően a magyar kötvénypiac is megközelítette a régiós piacok átlagát (6. ábra). A szlovén piac az átlagnál némileg alacsonyabb, míg a román piacon a kötvénypiac fejletlen, szinte egyáltalán nem történik rajta kötvénykibocsátás. A számításba vett országokat lorgova és Ong (2008) a kontinens fejlődő piacaiként is emlegeti, mivel e tagállamok piaci mechanizmusainak, tőkepiaci szabályozói keretrendszereinek kiépülése csak az 1990-es évek elején kezdődött meg. Habár azóta a térség piacai számottevő bővülésen mentek át, amint arra az Európai Bizottság (2017) kötvénypiaci elemzése is rámutat, a régió kötvénypiacát még mindig a centrumországokhoz képest alacsonyabb fejlettségi fok jellemzi, ahol a kibocsátók zöme első ízben jelenik meg a kötvénypiacon, illetve sok potenciális kibocsátó még csak ismerkedik a kötvénypiacon keresztüli forrásbevonás folyamatával.

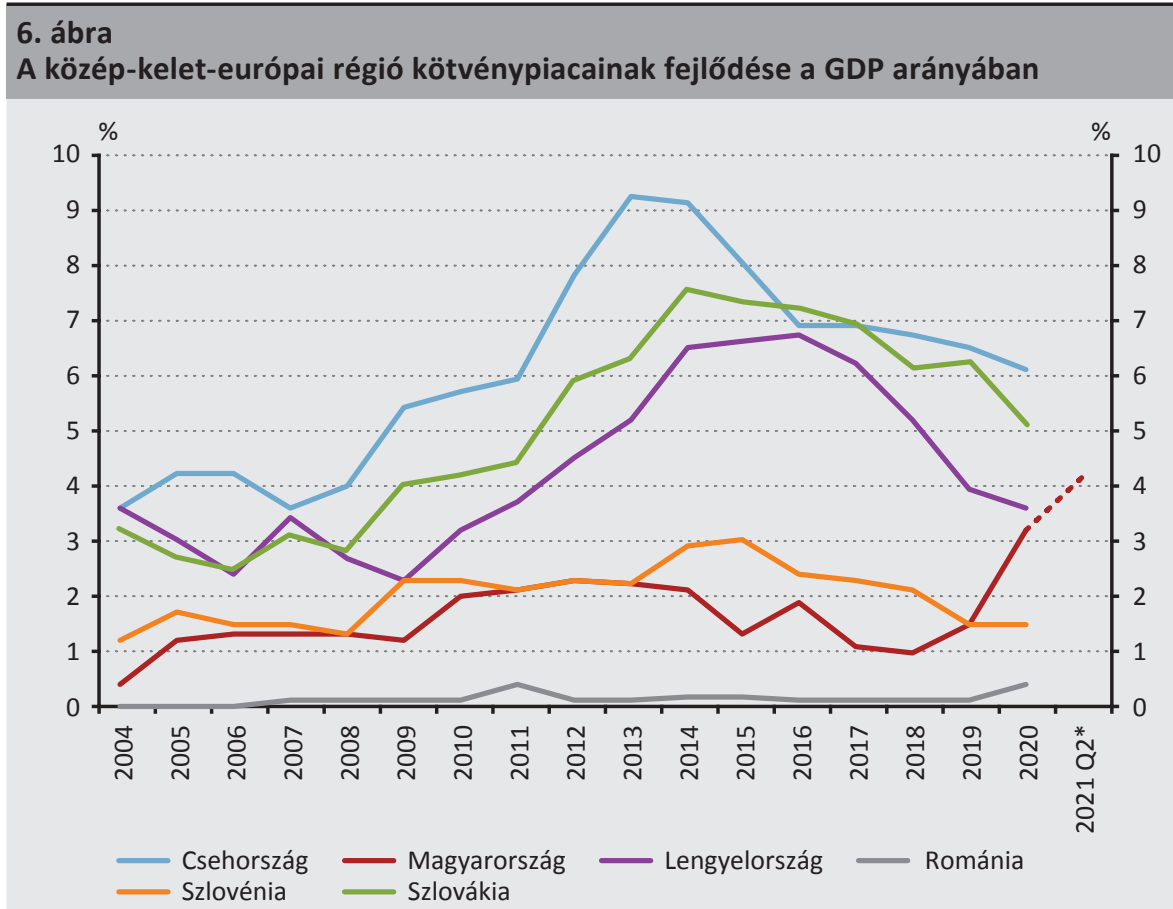

Megjegyzés: * A magyar kötvénypiac méretének a 2021 második negyedévének végére vonatkozó értéke a jegybank becslései alapján került megállapításra.

Forrás: Eurostat, MNB 
A 2008-as válságot követő években a kötvénypiac szerepe jelentősen emelkedett a cseh, szlovák és lengyel piacon, a kötvényállomány GDP-hez viszonyított aránya ezekben az országokban több mint duplájára nőtt. Mindhárom piacon megfigyelhető, hogy az elmúlt években a kötvényibocsátási kedv alábbhagyott, aminek hátterében egyrészt a vállalatok számára rendelkezésre álló bankhitelek kedvező kamatjai, valamint a GDP hatás állhatott. A cseh piacon a csúcsot jelentő 9,2 százalékról 6,1 százalékra, a szlovák piacon 7,5 százalékról 5,1 százalékra, míg a lengyel piacon 6,7 százalékról 3,6 százalékra esett vissza az arány az elmúlt években. A szlovén és a magyar piacon ilyen mértékű volatilitás nem volt megfigyelhető, a válság következtében mindkét országban átmenetileg nőtt a kötvénypiac szerepe. Ám míg Szlovénia esetében 2020 végére a GDP-hez viszonyított arány csak minimálisan haladta meg a válság idején lévő szintet, addig a magyar kötvénypiac - elsősorban az MNB Növekedési Kötvényprogramjának nyomán - tartós növekedést produkálva 2020 végére a historikus csúcsot jelentő 3,2 százalékon állt. Becsléseink szerint 2021 júniusának végére a magyar piac megközelíthette a GDP 4,2 százalékát, ami csak 0,3 százalékponttal marad el a V4-országok átlagától.

\subsubsection{Lengyel kötvénypiac}

A lengyel vállalatok által kibocsátott kötvények állománya 2020 végén 18,3 milliárd euróra volt tehető, mely az ország GDP-jének 3,6 százalékával egyenértékű, vagyis Lengyelország nominálisan a közép-kelet-európai régió legnagyobb piacát mondhatja magáénak. A lengyel vállalatikötvény-piac a legintenzívebb növekedést a 2008-2009-es gazdasági válságot követő időszakban élte meg (7. ábra), amiben jelentős szerepet játszott az első hitelinstrumentumok számára szervezett lengyelországi piac, a Catalyst-rendszer 2009-es bevezetése. A Varsói Tőzsde (WSE) két kiskereskedelmi piacot üzemeltet, a BondSpot pedig két nagykereskedelmi piacot múködtet a Catalyst struktúrában. A tőzsdének és a BondSpot-nak egyaránt dematerializált pénzügyi instrumentumai, így például vállalati kötvényei vannak. A tőzsde által szabályozott kiskereskedelmi piacon legalább 200 ezer eurót kell elérnie a kötvénykibocsátásnak, míg a BondSpot által múködtetett nagykereskedelmi piacon ez a belépési küszöb 5 millió zloty (kb. 1,08 millió euro).?

7 2021. szeptember 21-i árfolyamon számolva 


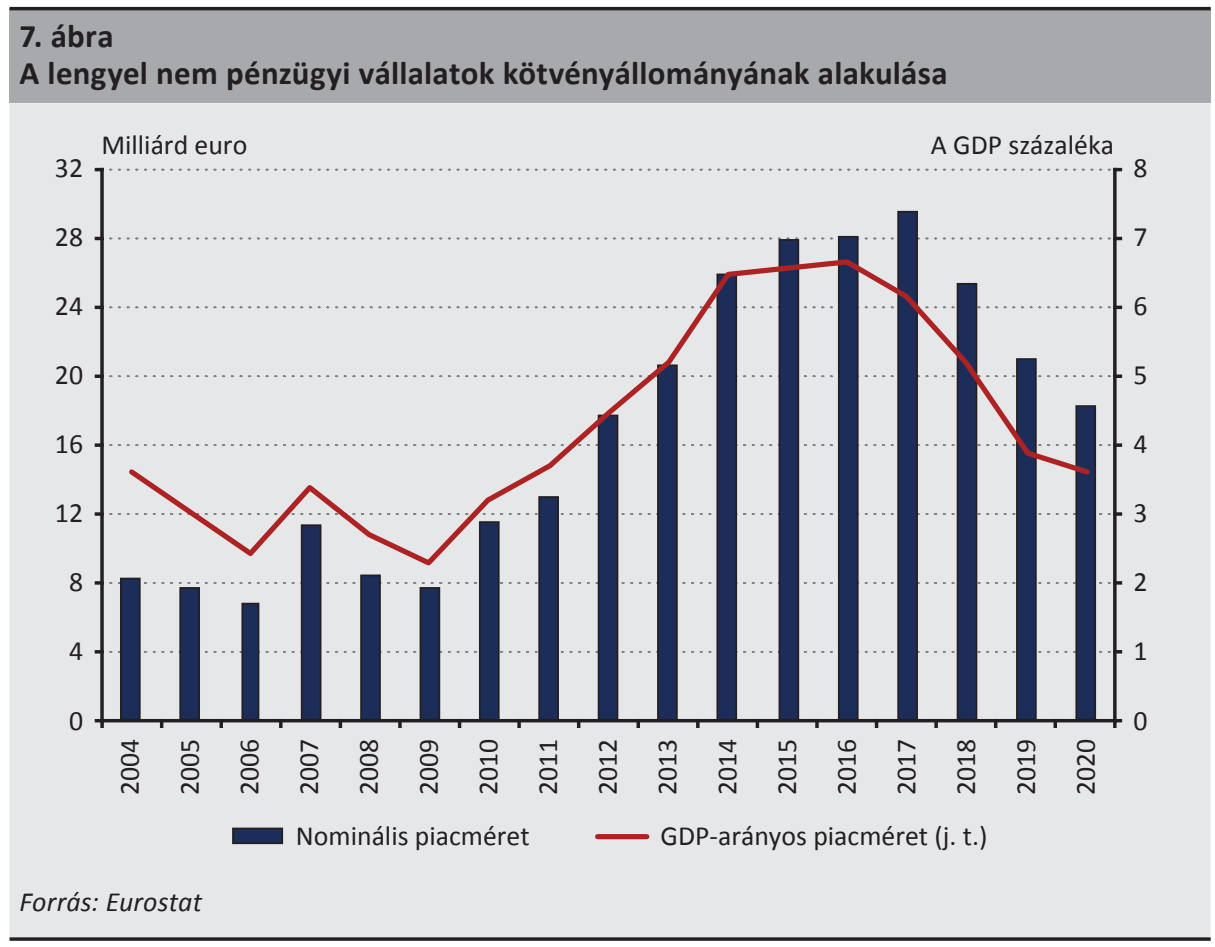

A Bloomberg kötvényadatbázisa ${ }^{8}$ szerint az aktív lengyel vállalati kötvények állománya szinte kizárólag zlotyban denominált, a papírok 75 százaléka változó kamatozású, 54 százaléka bullet típusú tőketörlesztéshez kapcsolódik. Az értékpapír-sorozatok átlagos kibocsátási névértéke (35 millió euro) és átlagos futamideje (7,1 év) regionális viszonylatban alacsonynak számít. A lengyel piacot a térségbeli országok összevetésében alacsonyabb kibocsátói és ágazati koncentráció jellemzi. Az ország legnagyobb vállalatikötvény-kibocsátójának minősülő energetikai konszern, a Tauron Polska s.a. a teljes piaci állománynak mindössze 15 százalékát adja, és az öt legnagyobb kibocsátó is „csak” a piac 63 százalékát fedi le úgy, hogy ezen vállalatok egymáshoz képesti piaci részesedése között sincsen drasztikus különbség. A kötvénypiaci állomány több mint 50 kibocsátóhoz kapcsolódik, vagyis az értékpapírpiacon keresztüli forrásbevonással a nagyvállalatok tágabb köre él, mint más régiós tagállamokban. A kötvénypiac ágazati megbontásában kiemelt pozíciója van a közműszolgáltatásoknak és energetikának, összesen 38 százalékos részesedéssel, a távközléshez és telekommunikációhoz a lengyel vállalatikötvény-állomány 16 százaléka, a kőolajfinomításhoz, valamint a bányászathoz és fémfeldolgozáshoz pedig 10-10 százaléka kötődött (8. ábra).

\footnotetext{
${ }^{8}$ a 2021. április 1-jei lekérdezés szerint
} 


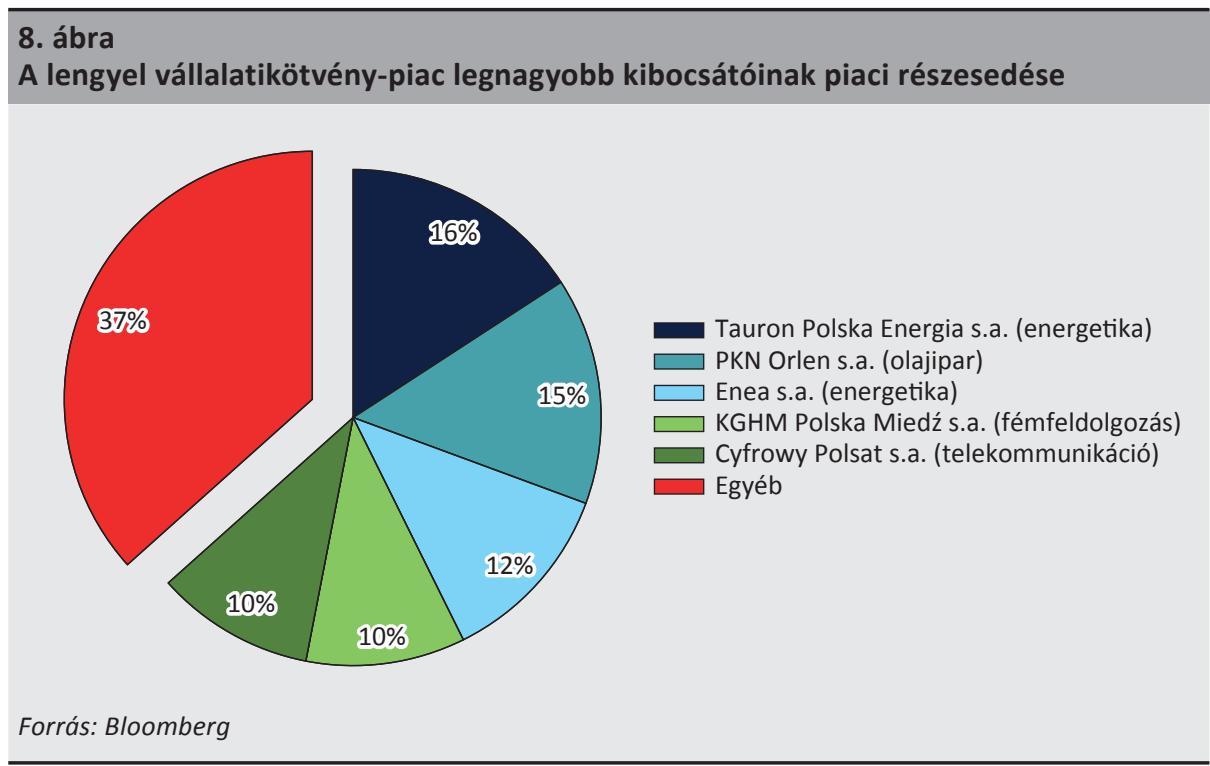

\subsubsection{Cseh kötvénypiac}

A csehországi székhelyű nem pénzügyi vállalatok által kibocsátott vállalati kötvények állománya 2020 végén meghaladta a 13 milliárd eurót, és 6,1 százalékos GDP arányos méretével a cseh kötvénypiac minősült a régióban a legfejlettebbnek. A vállalati kötvények állománya a 2008-2009-es gazdasági világválságot követően indult szignifikáns növekedésnek, és a piac 2013 végére érte el GDP-arányos méretének csúcsát (9,2 százalék), míg nominálisan számítva 2019-ben volt a legnagyobb (14,8 milliárd euro). A kötvényállomány nominális növekedése ellenére az erőteljes GDPhatás miatt a piac bruttó hazai termékhez viszonyított aránya a 2013-as csúcs óta folyamatosan csökken. A 2020-as év a kötvénypiac zsugorodását hozta, ám az év végén mért 13,1 milliárd eurós értékpapírállomány még így is 3,5-szerese a 2004 év végi piacméretnek (9. ábra). Megállapítható, hogy a kötvénykibocsátáson keresztüli forrásbevonással jellemzően a nagyvállalatok egy szűk köre él csak. A jelenség okát a cseh pénzügyminisztérium az információs korlátoknak, a KKV-szektorra jellemző pénzügyi tudáshiánynak és a szegmensre jól targetált, kedvező feltételek mellett igénybe vehető bankhiteleknek tulajdonítja (Ministry of Finance of the Czech Republic 2018). 


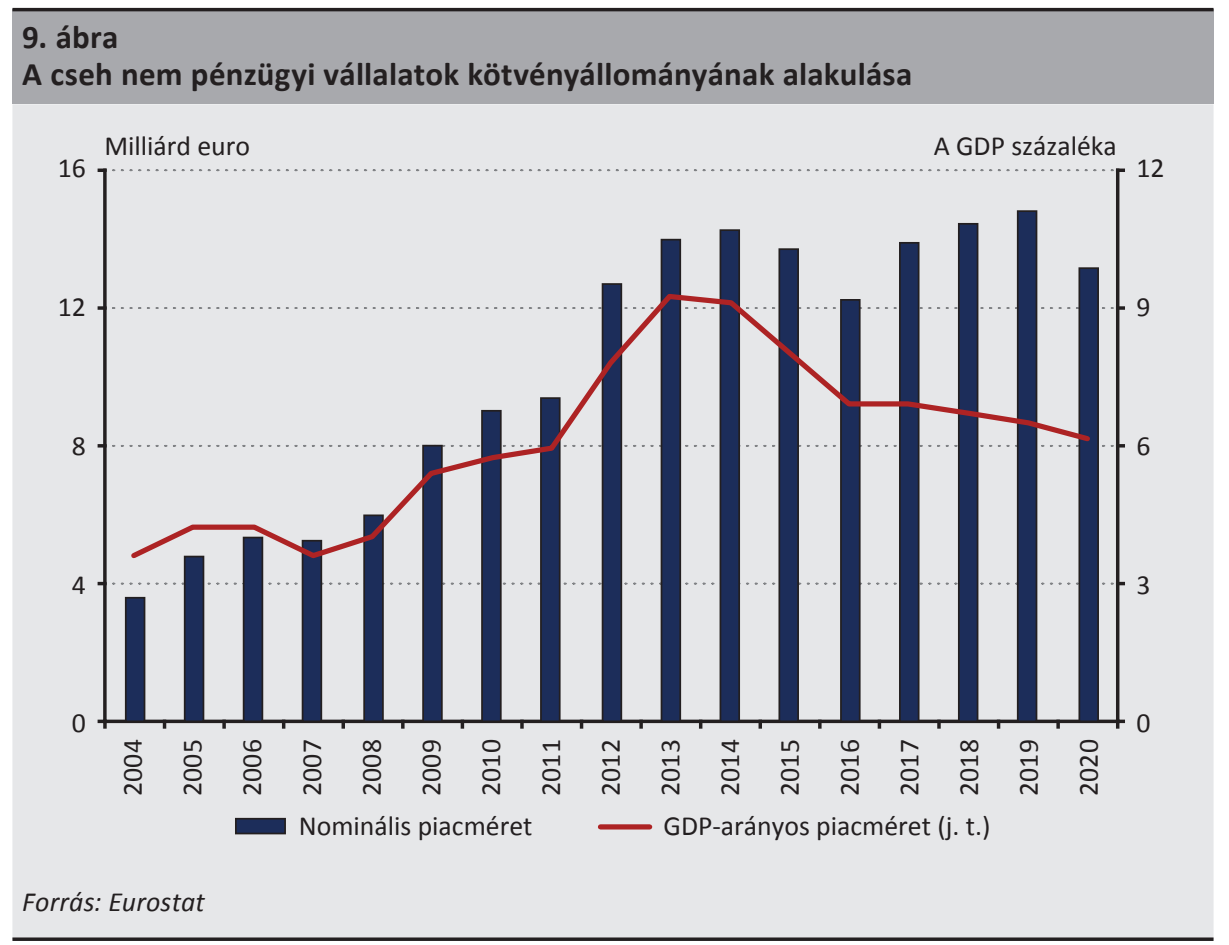

A Bloomberg adatai szerint a cseh vállalatikötvény-piacon a külföldi devizában denominált, fix kamatozású kötvények vannak többségben, melyek a régiós piacok átlagánál hosszabb futamidővel és nagyobb átlagos kibocsátási névértékkel rendelkeznek. A piaci kötvényállomány 74 százaléka euróban denominált, és mindössze 18 százaléka került forgalomba cseh koronában. A kamatozás típusa szerinti megbontásban a fix kamatozású értékpapírok az állomány 90 százalékát teszik ki, a tőketörlesztés típusa szerinti megbontásban pedig 46 százalék a bullet értékpapírok részaránya. A cseh vállalati kötvények kibocsátáskori átlagos futamideje 9,6 év, mely érdemben meghaladja a lengyel piac értékpapírjainak azonos mutatóját. A cseh vállalati kötvények átlagos kibocsátási névértéke 178 millió euro, mely ötszöröse a lengyel piacot jellemző átlagos kibocsátási méretnek.

A csehországi székhelyű nem pénzügyi vállalatok piacát rendkívül erős kibocsátói és ágazati koncentráció jellemzi (10. ábra), a legnagyobb kibocsátónak minősülő, meghatározó állami részesedéssel rendelkező energetikai vállalat, a ČEZ a.s. 18 kötvénysorozat révén pedig 37 százalék piaci részesedéssel rendelkezett. Az 5 legnagyobb kibocsátó a kötvénypiaci állomány négyötödét teszi ki. A kibocsátások ágazati megoszlásából a jelentős beruházási igénnyel múködő szektorok kötvénypiaci aktivitása olvasható ki. Az energiatermelés és a közműszolgáltatások piaci részaránya megközelíti a teljes állomány 70 százalékát, míg a szerencsejáték szegmens - egy 


\section{0. ábra}

A cseh vállalatikötvény-piac legnagyobb kibocsátóinak piaci részesedése

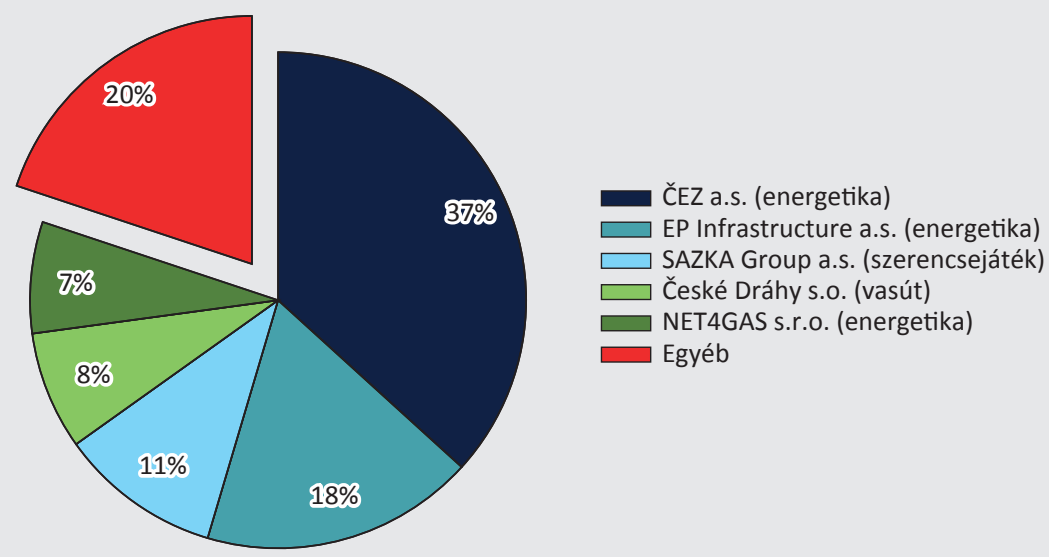

Forrás: Bloomberg

kibocsátó kötvényeinek köszönhetően - 11 százalék részesedést mondhat magáénak. A cseh vállalatikötvény-piac a vizsgálat időpontjában 38 kibocsátó értékpapírjaiból tevődött össze.

\section{A jegybankok vállalati eszközvásárlási programjai}

A vállalati kötvények piacának alakulásában és a koronavírus-járvány jelentette válsághelyzet utáni gazdaságélénkítésben jelentős szerepet játszanak az egyes jegybanki eszközvásárlási programok, amelyek a szakemberek által már megfogalmazott strukturális problémákra reflektálva kívánnak a vállalati forrásbevonási lehetőségek feltételein javítani. Az eszközvásárlási programok lehetőséget nyújtanak a kötvénypiaci likviditás javítására, a hozamfelárak csökkentésére, de legfőbb céljuk a monetáris politikai transzmissziós csatorna hatékonyságának javítása. Utóbbi különösen fontos azon jegybankok számára, ahol inflációs célkövető monetáris rezsimet alkalmaznak. A válságkezeléshez kapcsolódóan számos jegybank bővítette a monetáris politikai eszköztárát, és többük fordult a vállalatikötvény-piachoz, hogy elsődleges és másodlagos piacon vásároljon kötvényeket. Az elmúlt időszak fényében megelőlegezhető, hogy a jegybankok gyorsan reagáltak a Covid19-járvány okozta gazdasági válságra, ez pedig a gazdasági helyreállítás hatékonyságát is érdemben fokozhatja.

\subsection{Az Európai Központi Bank vállalatikötvény-vásárlási programja}

Az Európai Központi Bank (EKB) 2016. március 10-én jelentette be az eszközvásárlási programja részeként a kötvényvásárlási programját (Corporate Sector Purchase Programme, CSPP), amelynek célja a további monetáris politikai lazítás és az euro- 
övezeti vállalatok finanszírozási kondíciójának javítása volt. A program során az EKB befektetésre ajánlott minősítésű, euróban denominált, euroövezeti nem pénzügyi vállalatok értékapírjait vásárolja elsődleges és másodpiacon egyaránt, melynek hátralévő futamideje 6 hónap és 30 év között van. Az eszközvásárlási programot a jegybank 2018-ban átmenetileg leállította, ugyanakkor a piaci folyamatok alapján a kormányzótanács 2019. november 1-től szükségesnek látta újraindítani a nettó vásárlásokat. Ezenfelül nemcsak a hagyományos APP-n (Asset Purchase Programme) belül, hanem a 2020 márciusában a pandémia miatt bejelentetett PEPP (Pandemic Emergency Purchase Programme) keretében is vásárol az EKB vállalati kötvényt, amivel a Covid19 okozta gazdasági visszaesésre ad gyors és célzott választ.

A CSPP-program hatásaival foglalkozó De Santis és Zaghini (2019) 12 ezer kötvényt vizsgált, melyek kibocsátása 2013 októbere 2018 júniusa között történt. Megállapították, hogy a kötvényvásárlási program szignifikánsan hozzájárult a vállalatikötvény-piac bővüléséhez a 2016. március 10-i bejelentést követő két évben. A vizsgált kibocsátásokat két csoportba osztották: a vásárlási program követelményeinek megfelelőre, illetve nem megfelelőre, ez utóbbi a kutatás kontrollcsoportjaként szolgált. A szerzőpáros arra a következtetésre jutott, hogy az euróban történő kötvénykibocsátás valószínúsége 14 százalékkal magasabb volt abban a csoportban, amelyben a kibocsátások megfeleltek a program követelményeinek, mint a másik csoportban. Az eredmény akkor is megállja a helyét, ha a kontrollcsoportban csupán nem banki, illetve befektetési minősítésű kibocsátók szerepelnek.

Kiemelendő továbbá, hogy a piaci szereplők alkalmazkodása bizonyos esetekben már a verbális intervenció hatására megkezdődött, melyre jó példa, hogy a (benchmark) állampapírhozamhoz viszonyított kamatfelárak 2016 márciusában az Európai Központi Bank kötvényvásárlási programjának bejelentése után csökkenni kezdtek. A vállalatikötvény-piacon 25 bázispontos csökkenés volt tapasztalható a nem befektetési minősítésű kötvények tekintetében, közel 20 bázispontos a nem pénzügyi vállalatok által kibocsátott kötvények, valamint 5 bázispontos mérséklődés a pénzügyi intézetek által kibocsátott vállalati kötvények esetében (EKB 2016).

\subsection{A Bank of England kötvénykibocsátási programjának hatása}

A brit jegybank a Brexit-referendum lebonyolítását követően gazdaságélénkítési célból 2016 augusztusában elindította a 10 milliárd font keretösszegú vállalati kötvénykibocsátási programját ${ }^{9}$, melynek keretében fontban denominált, befektetésre ajánlott minősítésű, nem pénzügyi vállalatok által kibocsátott kötvényeket vásárolt. A program célja a kötvénypiaci hozamfelár csökkentése a befektetési aktivitás

\footnotetext{
${ }^{9}$ A brit jegybank 2020 áprilisában a kötvénykibocsátási program keretösszegének 10 milliárd fonttal történő emeléséről döntött, így az új keretösszeg 20 milliárd font. https://www.bankofengland.co.uk/markets/ market-notices/2020/asset-purchase-facility-additional-corporate-bond-purchases. Letöltés ideje: 2020. június 19.
} 
növelésén keresztül, ami vonzóbbá teszi a kötvényekből történő finanszírozást, és kibocsátásra ösztönzi a vállalatokat. A fontban denominált kötvények számának növekedése mellett - hasonlóan az EKB programjához - a bejelentést követően a kötvények állampapírhoz viszonyított felárában szignifikáns csökkenés volt látható. Boneva szerzőtársaival (2018) a kötvénykibocsátási program kötvénypiaci hozamfelárra gyakorolt hatását vizsgálta. A fontban denominált vállalati kötvények felára a kockázatmentes állampapírhoz képest 13-14 bázisponttal csökkent ugyanazon vállalatok dollárban, illetve euróban denominált kötvényeihez képest, de a kötvényvásárlási program feltételeit nem teljesítő, ám befektetésre ajánlott fontkötvények hozamai is csökkentek, tehát ez az állomány is részesült a jegybanki program kedvező hatásaiból.

2021 májusában a Bank of England (2021) Monetáris Tanácsa felkérte az intézmény vezetését, hogy vizsgálja meg, hogy árstabilitásra vonatkozó elsődleges célja mellett miként tudná segíteni az Egyesült Királyság gazdaságának klímasemleges átalakulását. A jegybank e törekvések részeként vállalatikötvény-portfóliójának zöldítését jelentette be, vitairatot téve közzé a fenntarthatósági kötvények relevanciáját növelő elvekről és eszközökről.

\subsection{További vállalatikötvény-vásárlási programok indítása az elmúlt időszakban}

2020 májusában a Covid19 okozta gazdasági válság leküzdésének és a piaci likviditás növelésének céljából a Fed elindította kötvényvásárlási programját, melynek során főként befektetésre ajánlott minősítésű vállalati kötvények és kötvény-ETF-ek vásárlására biztosított hitelt a US Treasury által alapított különleges célú gazdasági egységeken (SPV) keresztül, melynek köszönhetően a megvett papírok nem a Fed mérlegébe kerültek. A program bejelentésének hatására a vállalati kötvény-spreadek csökkenni kezdtek, habár még mindig a Covid19 előtti szint felett vannak. ${ }^{10}$ További pozitívum, hogy a 2020. március 17. és május 19. között kibocsátott, befektetésre javasolt kötvények értéke 675 milliárd dollárt tett ki, ami 100 milliárd dollárral haladta meg a 2019 első felében kibocsátott összeget. A vállalatok hitelcélok tekintetében a kibocsátásból származó bevételek döntő többségét általános likviditási célokra, valamint refinanszírozásra fordították (S\&P Global 2020). A trend folytatódott az év későbbi részében is: a 2020-as évben, már szeptemberben, mind a befektetésre ajánlott, mind a spekulatív kategóriájú vállalati kötvények kibocsátása megdöntötte a korábbi évek rekordjait a Moody's jelentése szerint (Lonski et al. 2020).

\footnotetext{
${ }^{10}$ Forrás: https://www.advisorperspectives.com/commentaries/2020/05/26/the-feds-corporate-bond-buyingprograms-faqs. Letöltés ideje: 2021. január 15.
} 
2020 májusában a Bank of Canada a Fed-hez hasonlóan elindította 12 hónapos vállalati kötvényvásárlási programját, melynek során 10 milliárdos keretösszegig vásárol kanadai dollárban denominált, legalább BBB minősítésű kötvényeket a másodpiacon. A program elsődleges célja, hogy a vállalatikötvény-piac likviditásának élénkítésével a vírushelyzetben érintett vállalatok a múködésükhöz szükséges hosszú távú finanszírozáshoz juthassanak. ${ }^{11}$

Az északi országok közül eddig Svédországban merült fel, hogy az EKB-hoz hasonlóan a Riksbank, a svéd jegybank is vásároljon vállalati kötvényeket. A svéd piacon megtalálható 290 vállalati kötvénynek ${ }^{12}$ kevesebb mint harmada, 79 rendelkezett minősítéssel a 2020. januári adatok szerint (Lindeberg 2020). A Riksbank végül a Covid19-járványra reagáló intézkedéscsomagja részeként, 2020 szeptemberében indította el kötvényvásárlási programját, melynek keretében befektetésre ajánlott hitelminősítéssel rendelkező, legfeljebb 5 éves hátralévő futamidővel rendelkező, svédországi székhelyű vállalatok kötvényeit vásárolja. A svéd jegybank 2021 januárja óta az úgynevezett negative screening ${ }^{13}$ módszerét alkalmazva kizárólag a nemzetközi fenntarthatósági sztenderdekkel összhangban forgalomba hozott vállalati kötvényeket vásárol.

\section{A magyar vállalatikötvény-piac helyzete és a Növekedési Kötvény- program}

\subsection{A magyar nem pénzügyi vállalatok forrásai 2019 előtt}

A magyar nem pénzügyi vállalatok forrásain belül elhanyagolható mértékű a kötvényállomány (11. ábra). A magyar vállalatok esetében az elmúlt 20 évben a tulajdonosi részesedések meghatározó mértékűek voltak, és a GDP 100-150 százaléka körül alakultak, de a vállalatok forrásaiban jelentős a külföldi anyavállalatoktól kapott tulajdonosi hitelek állománya is. Ugyanakkor a magyar vállalatok többségének külső forrás bevonáskor a bankhitel a reális opció attól eltekintve, hogy a GDP-arányos értéke mindössze 20 százalék körül alakult, ami alacsonyabb az uniós országok esetében mérhető arányszámnál. A kötvényen keresztüli forrásbevonás - a Növekedési Kötvényprogram elindulása előtt - a vállalatok szúk körének volt valós alternatíva, és volumene a GDP mindössze 1 százaléka körül alakult.

${ }^{11}$ Corporate bond purchase program (CBPP) - Term Sheet. https://www.bankofcanada.ca/markets/marketoperations-liquidity-provision/market-operations-programs-and-facilities/corporate-bond-purchaseprogram/corporate-bond-purchase-program-cbpp-term-sheet/. Letöltés ideje: 2021. január 18.

${ }^{12} \mathrm{Az}$ adat mind a pénzügyi, mind a nem pénzügyi vállalati kötvényeket tartalmazza.

${ }^{13}$ A fenntarthatósági szempontoknak megfelelő kötvények köre nem a zöld minősítés megléte, hanem bizonyos - ágazatokra, tevékenységekre - meghatározott restriktív normák és megkötések alapján szúkíthető le. 


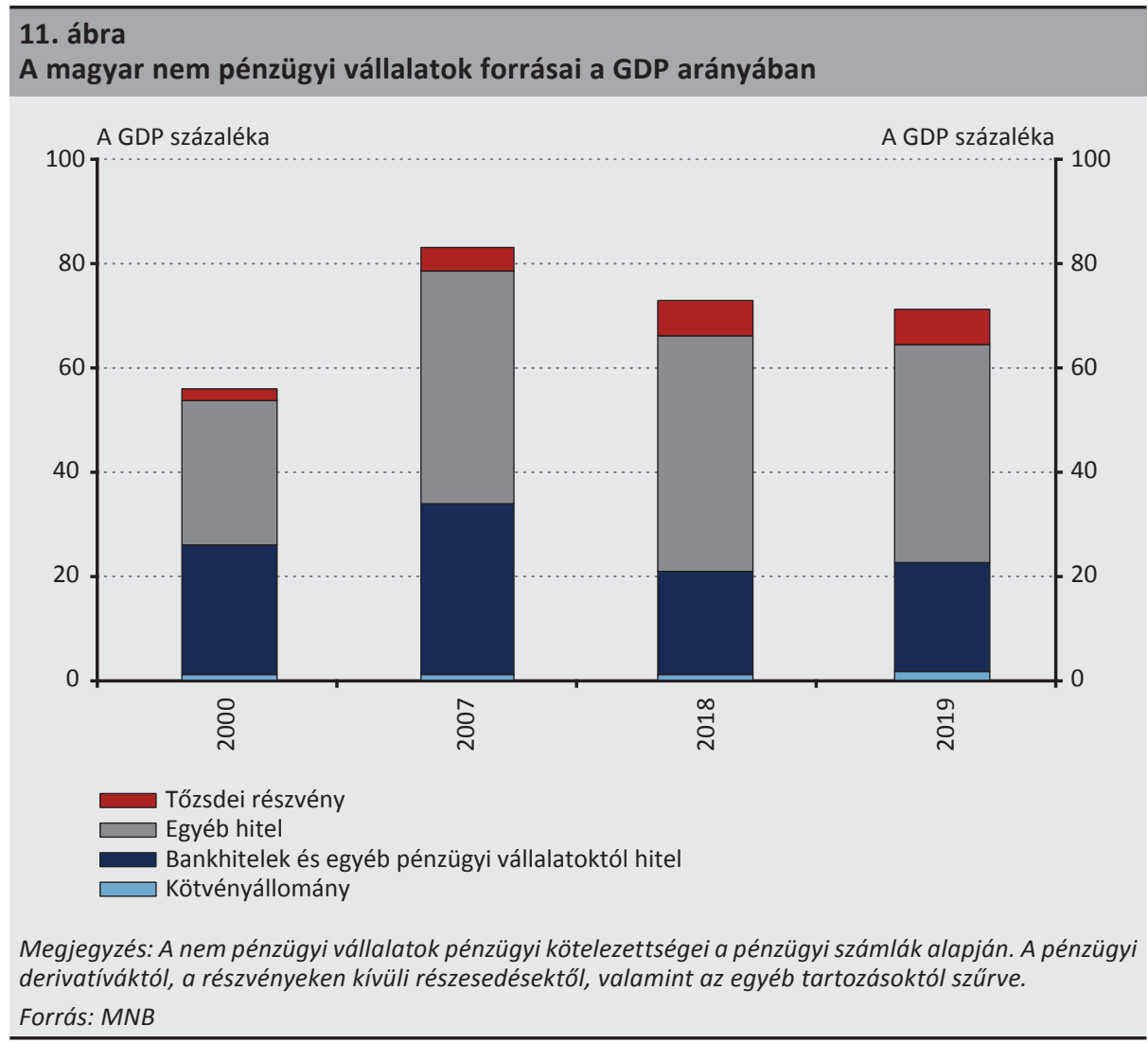

\subsection{A Növekedési Kötvényprogram elindítása}

A 2008-ban kirobbanó gazdasági és pénzügyi világválság Magyarországra történő begyúrűzése a hazai vállalati szektor adósságalapú finanszírozásában is jelentős zavarokat idézett elő. A vállalati finanszírozás struktúráját három kedvezőtlen trend jellemezte. Az első, hogy a banki hitelcsatorna esetében még a nemzetközi tendenciánál is jelentősebb mértékű beszűkülés volt tetten érhető, amelynek eredményeként a vállalatok, mindenekelőtt a KKV-k hitelállománya folyamatos apadásnak indult. A második, hogy a vállalati hitelek szerkezete sem a lejárat hossza, sem pedig a kamatozás típusa alapján nem mutatott egészséges képet. A harmadik pedig, hogy a tradicionálisan banki hitelezésre támaszkodó magyarországi vállalatok forrásbevonási diverzifikációja nemcsak az Európai Unió, de a közép-kelet-európai régió országainak átlagához képest is alacsony szinten volt. Az MNB a vállalatok finanszírozási lehetőségeinek javítása céljából a fenti trendeket célzottan javító monetáris politikai eszközökkel reagált. 
A jegybank elsőnek a banki hitelcsatorna kitisztítására fókuszálva indította el 2013 júniusában a Növekedési Hitelprogramot, mely a 2013-ra a válság előtti szint háromnegyedére visszaesett magyarországi vállalati hitelállományt kívánta újra növekedési pályára állítani. Mérlegelve a hazai KKV-szektor korlátozott hozzáférését a hosszabb lejáratú és rögzített kamatozású hitelekhez, az MNB a 2019 elején elindított Növekedési Hitelprogram Fix elnevezésű konstrukcióval járult hozzá a fix kamatozású hitelek arányának növekedéséhez, amely a vállalati hitelállomány szerkezetét tette egységesebbé. A vállalati forrásbevonás diverzifikációja ugyanakkor továbbra sem valósult meg, hiszen míg 2019-ben a bankhitelállomány a GDP 20 százalékával volt egyenértékű, addig a magyar vállalatikötvény-piac a bruttó hazai össztermék mindössze 1 százaléka körül alakult. Az MNB a hazai vállalatfinanszírozás több lábra állításának érdekében 2019 júliusában elindította a Növekedési Kötvényprogramot, amely a magyar vállalatikötvény-piac likviditásának bővítését célozza meg (MNB 2019).

A Növekedési Kötvényprogram a kötvénypiaci likviditás serkentésén keresztül próbálja meg javítani a monetáris transzmisszió hatékonyságát. Az NKP keretrendszere több ponton is merít az EKB vállalatikötvény-vásárlási programjából (CSPP). Az NKP keretében a jegybank a kibocsátóra és annak kötvényére vonatkozóan meghatározott feltételek mellett vásárol vállalati kötvényeket, elsődleges és másodlagos piacon egyaránt. A kötvényprogram elindítása óta eltelt időszakban a makrogazdasági helyzet, különösen a koronavírusos pandémia következtében fellépő változásokra reagálva az MNB Monetáris Tanácsa az NKP eredeti paramétereinek vonatkozásában több ízben is finomhangolással élt. A változások értelmében jelenleg olyan magyarországi székhelyű nem-pénzügyi nem-közvállalatok és közvállalatok lehetnek kibocsátók, amelyek a legutóbbi két üzleti év pénzügyi beszámolója szerint minimum 1 milliárd forintos mérlegfőösszeggel rendelkeznek. A kötvényprogram keretében kibocsátani kívánt értékpapírnak rendelkezni kell egy Európai Értékpapírpiaci Hatóság (ESMA) által elismert hitelminősítő legalább $B+$ fokozatot elérő minősítésével, a kibocsátás össznévértékének minimum egymilliárd forintnak, a futamidejének pedig 3 és 30 év közöttinek kell lennie. A forrásallokáció hatékonyságának növelése érdekében az MNB azt is elvárásként fogalmazza meg, hogy az NKP keretében kibocsátott kötvényeket a kibocsátó a forgalomba hozatalt követő 90 napon belül vezesse be a BÉT valamely kereskedési platformjára. A jegybanki eszközvásárlások következtében keletkező bankrendszeri többletlikviditást az MNB a preferenciális betéti eszköz révén semlegesíti.

\subsection{A Növekedési Kötvényprogramban történő kibocsátások}

A kötvényprogram keretében 2021 augusztusának végéig 63 vállalat 80 kötvénysorozatának sikeres forgalomba hozatalára került sor, a tranzakciókon keresztül pedig 1550 milliárd forint forrás bevonását hajtották végre a kibocsátók, míg az MNB névértéken vett kötvényvásárlásai pedig közel 905 milliárd forintra tehetők. Vásárlásai 
során az MNB nem alkalmaz ágazati preferenciát, így a kibocsátók szektorális megbontása is diverzifikált képet mutat, ugyanakkor jelentős arányban képviseltetik magukat a feldolgozóipari, valamint az ingatlanpiachoz kapcsolódó tevékenységű társaságok. A kötvények átlagos futamideje 9,3 év, átlagos hitelminősítésük pedig BB. A 80 kibocsátás esetében számított átlaghozam 2,49 százalék, az aukciók átlagos állampapírhozam feletti felára pedig mindössze 27 bázispont, ami arról tanúskodik, hogy az NKP résztvevői kedvező költségek mellett jutottak forráshoz. Az NKP-ban részt vevő társaságok a bevont forrásokat mindenekelőtt versenyképességüket növelő beruházásokra és vállalatfelvásárlásokra, illetve kisebb hányadát már meglévő, kedvezőtlenebb hiteleik refinanszírozására fordították.

Az NKP elindítása előtt a hazai nem pénzügyi vállalatok kötvénypiacának mérete mindössze a GDP 1 százaléka körül alakult, és néhány vállalat jellemzően külföldi devizában kibocsátott kötvényére korlátozódott. Az NKP-s kibocsátások jelentős hozzájárulásának köszönhetően 2021 második negyedévének végén becsléseink szerint a vállalati kötvények állománya megközelíthette a bruttó hazai termék 4,2 százalékát, a nominálisan számított piacméret pedig csaknem megötszöröződött a kötvényprogram elindítása óta (12. ábra). Az MNB adatai szerint 2019 júniusa és 2021 júliusa között a vállalati kötvényeket kibocsátók és a forgalomba hozott kötvénysorozatok száma egyaránt több mint kétszeresére emelkedett, a forintban denominált értékpapírok aránya a teljes állományon belül 10 százalék alatti szintről 60 százalék felé nőtt, a kötvénypiac ágazati és kibocsátói koncentrációja pedig számottevően csökkent. A magyar kötvénypiac az NKP elindítása óta tehát nemcsak méretében zárkózott fel a regionális országok piacainak átlagához, de a piac szerkezete is lényegesen egészségesebb, diverzifikáltabb lett. A magyar tőkepiac fontos mérföldköveként 2020 augusztusában az NKP keretében került sor az első hazai zöld vállalati kötvény kibocsátására, amelyet azóta további 10 fenntarthatósági kritériumoknak megfelelő kötvénysorozat követett.

Az NKP-nak köszönhetően jelentősen nőtt a tőzsdei kereskedési helyszínre bevezetett vállalatikötvény-sorozatok száma. Míg 2019 végén a BÉT-en csak 8 vállalati kötvény volt megtalálható, addig 2021 júliusának végén már 69, vagyis a program elindítása óta a tőzsdei platformokon jelen lévő papírok száma közel kilencszeresére nőtt. A tőzsdei bevezetés kötelezettsége segíti a piaci transzparencia növekedését, valamint a befektetők védelmét, a kötvénykibocsátási folyamat és a tőzsdei bevezetésben való részvétel pedig erősíti a hazai vállalatok pénzügyi és tőkepiaci tudásbázisát is. 


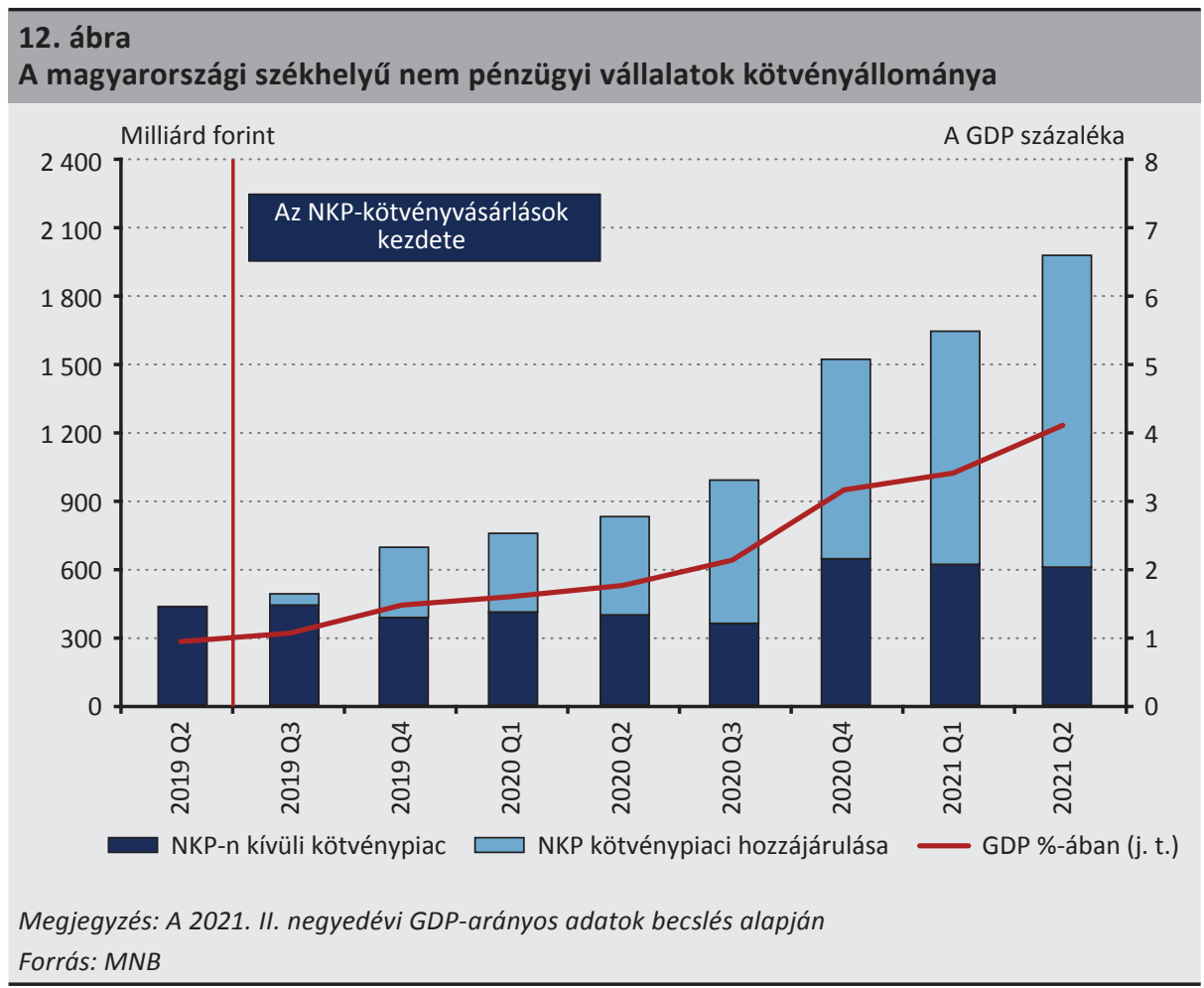

A teljes hazai vállalatikötvény-piac tulajdonosi megoszlása diverzifikált képet mutat, ugyanakkor az NKP-nak köszönhetően számottevően változtak a tulajdonosi csoportokhoz kötődő arányok, a legjelentősebb befektetők a jegybank és a hitelintézetek lettek (13. ábra). A legfrissebb, 2021. júniusi értékpapír-statisztikai adatok szerint a több mint 2000 milliárd forintot kitevő kötvénypiac állományának 35 százalékát az MNB, 31 százalékát hitelintézetek, 7 százalékát pedig intézményi befektetők tartották mérlegükben. A külföldi rezidensek által tulajdonolt értékpapírok aggregátuma a piac negyedét jelentette. A nem hazai rezidensek aránya az NKP elindításának hatására számottevően csökkent. 


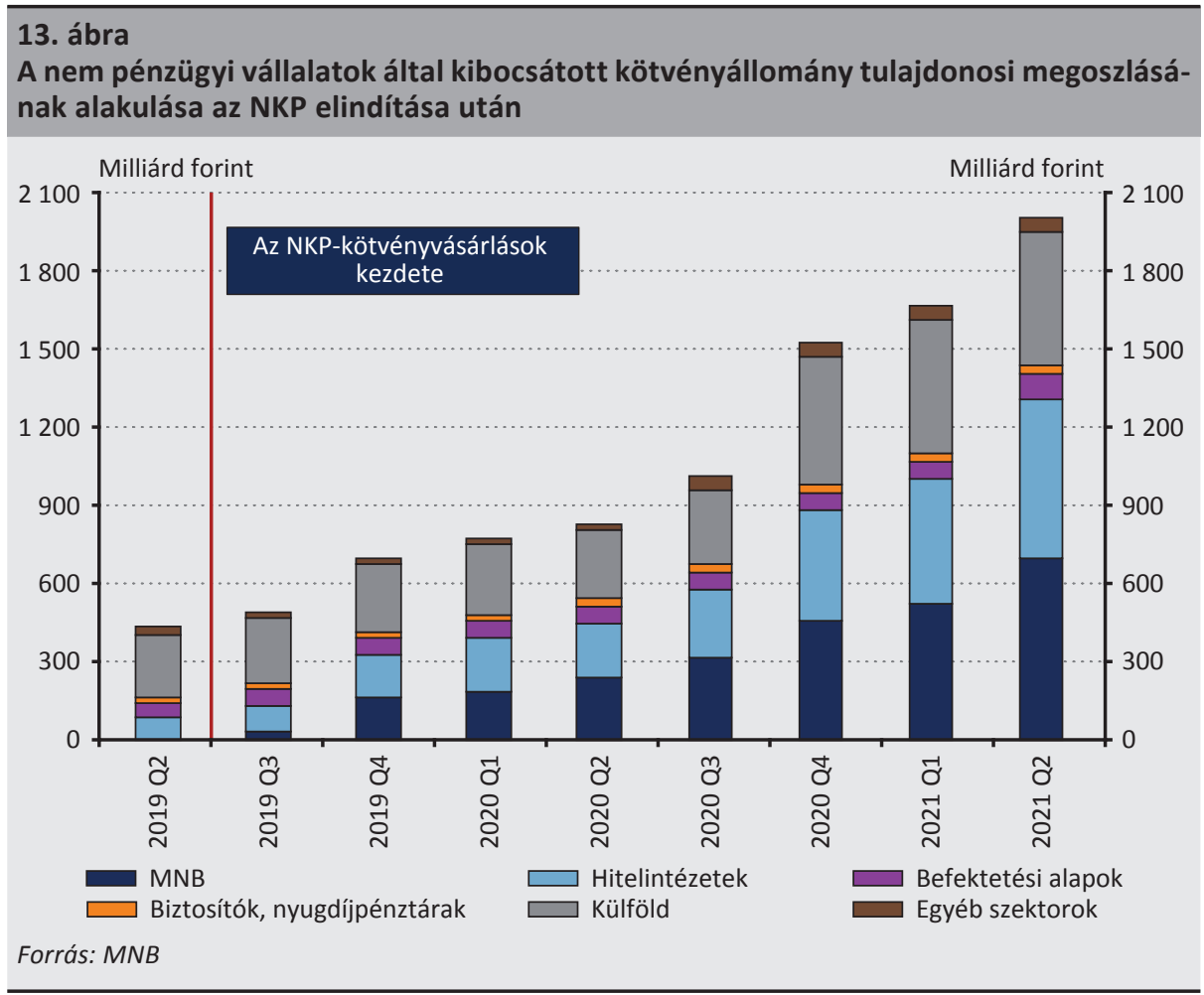

\section{6. Összegzés és következtetés}

A fejlett vállalatikötvény-piacnak a gazdaságban betöltött fontos szerepét számos tanulmány alátámasztja. A vállalati kötvények alternatív finanszírozási formaként hozzájárulnak a piaci likviditás biztosításához, a források elérhetősége terén erősítik a vállalati szektor forrásbevonásának diverzifikációját, továbbá elősegítik a kedvezőbb forrásbevonási költségek kialakulását amellett, hogy nagyobb fokú transzparenciát biztosítanak a kötvényt kibocsátó vállalatokról, vagyis összességében javítják a piaci forrásallokáció hatékonyságát.

A 2000-es évek elejéhez viszonyítva a vállalatikötvény-állomány növekedése figyelhető meg mind a fejlett, mind a fejlődő piacok esetében. Ennek oka egyrészt az, hogy a válság során a banki hitelezés befagyásával a vállalatok felismerték az alternatív forrásbevonási lehetőségek szükségességét és fontosságát, másrészt a jegybankok is ösztönözni kezdték a vállalati kötvénykibocsátást a kötvényvásárlási programokon keresztül, ami elősegítette a piac bővülését és mélyítését. A vállalatikötvény-piac stabilizálására irányuló jegybanki eszközvásárlási programok újabb lendületet kaptak a Covid19 okozta krízis enyhítése céljából, ami a gazdasági visszaesés tompításához és a gyorsabb kilábaláshoz járul hozzá. Az amerikai piacon mutatott ugrásszerü 
növekedés a kibocsátásban azt bizonyítja, hogy a jegybank jelentős ösztönző szerepet tud játszani az értékpapírok piacán, egyúttal enyhítve a hirtelen megugró hozamok okozta turbulenciákat. Az MNB által indított Növekedési Kötvényprogram ugyancsak a vállalatikötvény-piac fejlesztését tűzte ki célul, figyelembe véve a korábbi jegybanki kezdeményezéseket.

A tanulmány megállapításai alapján arra következtethetünk, hogy a vállalati kötvények elősegítésére irányuló monetáris politikai lépések alapvetően kétféle módon jelenhetnek meg: az egyik, amikor a jegybank piacfejlesztési céllal hosszú távú stratégiaként a piaci likviditást fokozatosan növeli. A másik eset, amikor egy már jól működő piacon a jegybank a sokk hatására ideiglenesen kiszáradt likviditást pótolja, hogy minél kisebb gazdasági károk mellett történjen meg a helyreállás. Az így bemutatott módszerek alkalmazásával a központi bankok kulcsszerepet játszhatnak egy válság kezelésében azáltal, hogy hatékonyabb piacot és ellenállóbb gazdaságot teremtenek a finanszírozási formák diverzifikációja útján.

\section{Felhasznált irodalom}

Bank of England (2021): Options for greening the Bank of England's Corporate Bond Purchase Scheme. Discussion Paper, May. https://www.bankofengland.co.uk/-/media/ boe/files/paper/2021/options-for-greening-the-bank-of-englands-corporate-bond-purchase-scheme-discussion-paper.pdf?la=en\&hash=9BEA669AD3EC4B12D000B30078E4BE8ABD2CC5C1. Letöltés ideje: 2021. május 28.

Boneva, L. - de Roure, C. - Morley, B. (2018): The impact of the Bank of England's Corporate Bond Purchase Scheme on yield spreads. Staff working paper No. 719, Bank of England. https://doi.org/10.2139/ssrn.3149766

Çelik, S. - Demirtaş, G. - Isaksson, M (2020): Corporate Bond Market Trends, Emerging Risks and Monetary Policy. OECD Capital Market Series. http://www.oecd.org/corporate/ca/ Corporate-Bond-Market-Trends-Emerging-Risks-Monetary-Policy.pdf Letöltve: 2020 május 27.

CFA Intézet (2016): Secondary Corporate Bond Market Liquidity Report https://www. cfainstitute.org/-/media/documents/survey/bond-market-liquidity-survey-report.ashx. Letöltés ideje: 2020. május 20.

De Fiore, F. - Uhlig. H. (2015): Corporate Debt Structure and the Financial Crisis. ECB Working Paper No. 1759, Európai Központi Bank. https://www.ecb.europa.eu/pub/pdf/scpwps/ ecbwp1759.en.pdf

De Santis, R.A. - Zaghini, A. (2019): Unconventional monetary policy and corporate bond issuance. ECB Working paper No 2329, Európai Központi Bank. https://doi.org/10.2866/568 
Distenfeld, G. - Shah, A. (2014): High Yield: Equity-Like Returns... with Half the Risk? Alliance Bernstein. https://www.alliancebernstein.com/abcom/perspectives_web/market/retail/ equity-like-returns/equity-like-returns-whitepaper.pdf. Letöltés ideje: 2020. október 1.

EKB (2016): The corporate bond market and the ECB's corporate sector purchase programme. ECB Economic Bulletin, Issue 5/Box 2, Európai Központi Bank. https://www.ecb.europa. eu/pub/pdf/other/eb201605_focus02.en.pdf. Letöltés ideje: 2020. május 20.

Európai Bizottság (2017): Analysis of European Corporate Bond Markets. https://ec.europa. eu/info/sites/info/files/171120-corporate-bonds-analytical-report_en.pdf. Letöltés ideje: 2020. október 3.

Gormley T. - Johnson S. - Rhee C. (2006): Corporate Bonds: A Spare Tire in Emerging Markets? https://pdfs.semanticscholar.org/8490/817b1b140830c10f17d6e971d62b270198e0.pdf. Letöltés ideje: 2020. június 2.

Gostkowska-Drzewicka, M. (2014): Corporate Bond Market of Real Estate Development Companies in Poland. Financial Internet Quarterly „e-Finanse”, 10(1): 1-16. http://cejsh. icm.edu.pl/cejsh/element/bwmeta1.element.desklight-b5900d5e-604b-4a0e-8eebe0204299df5b/c/268.pdf. Letöltés ideje: 2020. június 2.

Gyntelberg, J. - Ma, G. - Remolona, E. (2005): Corporate Bond Markets in Asia. BIS Quarterly Review. December, pp. 83-93. https://www.researchgate.net/publication/4736044_ Corporate_Bond_Markets_in_Asia. Letöltés ideje: 2020. május 20.

Hakansson, N. (1999): The Role of a Corporate Bond Market in an Economy - and in Avoiding Crises. UC Berkeley: Research Program in Finance. https://escholarship.org/uc/ item/6sq4c6g0

Hill, A. - Callsen, G. (2019): Time to act - ICMA's 3rd study into the state and evolution of the European investment grade corporate bond secondary market. https://www.icmagroup. org/assets/documents/Regulatory/Secondary-markets/Time-to-act-ICMAs-3rd-study-intothe-state-and-evolution-of-the-European-investment-grade-corporate-bond-secondarymarket-040320.pdf. Letöltés ideje: 2020. május 20.

ICMA (2013): Economic Importance of the Corporate Bond Markets. International Capital Market Association. http://www.icmagroup.org/assets/documents/Media/ Brochures/2013/Corporate-Bond-Markets-March-2013.pdf. Letöltés ideje: 2020. június 2.

lorgova, S. - Ong, L.L. (2008): The Capital Markets of Emerging Europe: Institutions, Instruments and Investors. Working Paper 08/103, International Monetary Fund. https:// doi.org/10.5089/9781451869644.001 
Lindeberg, R. (2020): Swedish Bond Market Dysfunction Draws Central Bank Criticism. Bloomberg, május 28. https://www.bloomberg.com/news/articles/2020-05-28/bondmarket-dysfunction-in-sweden-draws-central-bank-criticism. Letöltés ideje: 2020. május 28.

Lonski, J. - Choi, Y.- Mukherjee, S. - Araujo Teixera, B. - Zandi, M. - Ferlez, M. (2020): RecordHigh Bond Issuance Aids Nascent Upturn. Moody's Analytics. https://www.moodys.com/ researchdocumentcontentpage.aspx?docid=PBC_1248577. Letöltés ideje: 2020. október 6.

Luengnaruemitchai, P. - Ong, L.L. (2005): An Anatomy of Corporate Bond Markets: Growing Pains and Knowledge Gains. IMF Working Paper 06/152, International Monetary Fund. https://doi.org/10.5089/9781451861716.001

Lund, S. - Woetzel, J. - Windhagen, E. - Dobbs, R. - Goldshtein, D. (2018): Rising Corporate Debt. Peril or Promise? McKinsey Global Institute. https://www.mckinsey.com/businessfunctions/strategy-and-corporate-finance/our-insights/rising-corporate-debt-peril-orpromise. Letöltés ideje: 2020. december 18.

MNB (2019): Növekedési Kötvényprogram elindításának jegybanki szempontjai és a konstrukció fóbb jellemzői. Magyar Nemzeti Bank. https://www.mnb.hu/letoltes/novekedesikotvenyprogram-hatteranyag.pdf. Letöltés ideje: 2020. szeptember 10.

Ministry of Finance of the Czech Republic (2018): National Strategy for the Development of the Capital Market of the Czech Republic 2019-2023. https://www.mfcr.cz/assets/en/ media/201903-National-Strategy-CZ-Capital-Market.pdf. Letöltés ideje: 2021. február 23.

S\&P Global (2020): Tidal wave of investment-grade bond issuance, prompted by Fed, rolls on. S\&P Global Ratings https://www.spglobal.com/marketintelligence/en/news-insights/ latest-news-headlines/tidal-wave-of-investment-grade-bond-issuance-prompted-by-fedrolls-on-58735558. Letöltés ideje: 2020. december 18.

Tendulkar, R. - Hancock, G. (2014): Corporate Bond Markets: A Global Perspective. Staff Working Paper, IOSCO Research Department. https://www.iosco.org/research/pdf/swp/ SW4-Corporate-Bond-Markets-Vol-1-A-global-perspective.pdf. Letöltés ideje: 2020. június 2.

Vazza, D. - Kraemer, N.W. - Gunter, E. (2018): 2018 Annual Global Corporate Default And Rating Transition Study. S\&P Global Ratings. https://www.spglobal.com/en/researchinsights/articles/2018-annual-global-corporate-default-and-rating-transition-study. Letöltés ideje: 2020. október 2. 